\title{
4,6-Dimethyl- $\alpha$-pyrone: a matrix isolation study of the photochemical generation of conjugated ketene, Dewar valence isomer and 1,3-dimethyl-cyclobutadiene
}

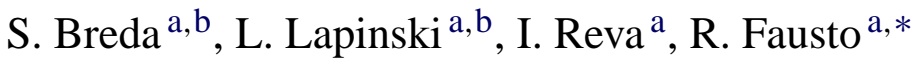 \\ ${ }^{a}$ Department of Chemistry, University of Coimbra, Coimbra P-3004-35, Portugal \\ ${ }^{\mathrm{b}}$ Institute of Physics, Polish Academy of Sciences, Warsaw PL-02-668, Poland
}

Received 5 June 2003; received in revised form 19 June 2003; accepted 8 July 2003

\begin{abstract}
A combined matrix isolation and molecular orbital study of the vibrational spectra and photochemistry of 4,6-dimethyl- $\alpha$-pyrone (DMAP) was undertaken. Two types of photoreactions: ring opening leading to conjugated ketene and valence isomerization to the Dewar form (1,5-dimethyl-2-oxa-3-oxobicyclo[2.2.0]hex-5-ene; DOOBH), occurred upon UV $(\lambda>315 \mathrm{~nm})$ irradiation. The latter reaction was efficient, whereas aldehyde-ketene was produced only in little amounts. In addition to the IR spectroscopic study of DMAP, the full mid-IR spectrum of the photoproduced DOOBH is reported and interpreted. Observation of 1,3-dimethyl-cyclobutadiene (DMCB), created by shorter wavelength UV irradiation $(\lambda>235 \mathrm{~nm})$ of DOOBH, is reported for the first time. In the matrices, DMCB forms a complex with $\mathrm{CO}_{2}$; the structure and IR absorption features of this cage confined DMCB- $\mathrm{CO}_{2}$ complex are also investigated.
\end{abstract}

(c) 2004 Elsevier B.V. All rights reserved.

Keywords: 4,6-Dimethyl- $\alpha$-pyrone; Matrix isolation; $\mathrm{DMCB}-\mathrm{CO}_{2}$ complex; Photoreaction; Dewar; Ketene

\section{Introduction}

Important, naturally occurring compounds and synthetic pesticides, such as coumarins, psoralens and chromones, that are known to be potent photosensitizers, possess pyrone moieties as their fundamental structural nucleus $[1,2]$. Pyrones are also very useful reagents in organic synthesis, e.g. in the Diels Alder reaction, and have been shown to exhibit interesting photochemical properties [3]. First reports on the photochemistry of $\alpha$-pyrones come from the early work of de Mayo [4] who observed an open-ring ester photoproduct generated from 4,6-dimethyl- $\alpha$-pyrone (1) dissolved in methanol. A conjugated aldehyde-ketene (2) was presumed to be the primary product of the photoreaction, although this intermediate species was not directly observed:
On the other hand, irradiation of a solution of $\alpha$-pyrone in ether at -10 to $-20^{\circ} \mathrm{C}$, carried out by Corey and Streith [5], resulted in isomerization of the compound to its Dewar valence isomer (3), 2-oxa-3-oxobicyclo[2.2.0]hex-5-ene ( $\beta$-lactone):

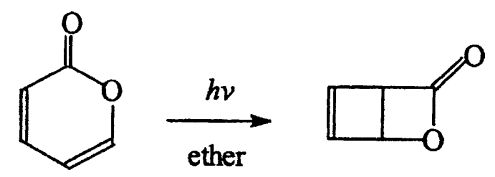

(3)

In the study of UV irradiated thin solid films layers of 4,6-dimethyl- $\alpha$-pyrone at $-190^{\circ} \mathrm{C}$, Guthrie et al. [6] were able to observe IR bands that could be attributed to<smiles>Cc1cc(C)oc(=O)c1</smiles>

(1)<smiles>CC(=O)/C=C(/C)C=O</smiles>
$\mathrm{CH}_{3} \mathrm{OH}$

\section{$\mathrm{CH}_{3} \mathrm{COCH}_{2} \mathrm{C}\left(\mathrm{CH}_{3}\right)=\mathrm{CH}-\mathrm{COOCH}_{3}$}

* Corresponding author.

E-mail address: rfausto@ci.uc.pt (R. Fausto). both photoproducts: Dewar valence isomer and conjugated aldehyde-ketene. This result indicated that both 
species could indeed be photoproduced from the reactant molecule.

In the present work, we report a combined matrix isolation and molecular orbital study of the vibrational spectra and photochemistry of 4,6-dimethyl- $\alpha$-pyrone (DMAP). Both types of photoreactions, ring opening leading to conjugated ketene and valence isomerization to the Dewar form, were observed, the latter reaction being much more efficient than the first one. In addition to the photochemical and spectroscopic study of the IR spectrum of DMAP, the full mid-IR spectrum of its Dewar valence isomer is reported and interpreted. Observation of the antiaromatic 1,3-dimethyl-cyclobutadiene, created by shorter wavelength UV irradiation $(\lambda>235 \mathrm{~nm})$ of the DMAP Dewar isomer, is reported for the first time, and the IR absorption features of its complex with $\mathrm{CO}_{2}$ are analyzed.

\section{Experimental}

DMAP was obtained from Aldrich. A sample of the compound was placed in a glass tube protected against light and connected to the chamber of the cryostat with a needle valve. Before cooling down the cryostat, the compound was degassed by the standard freeze-pump-thaw procedure and, subsequently, the vapors over the compound in the tube were evacuated several times at room temperature. This approach enabled removal of possible volatile impurities, allowing an additional purification of the compound, immediately before each experiment. In order to deposit a matrix, the vapor of DMAP was introduced into the cryostat chamber together with large excess of the host matrix gas (argon N60, from Air Liquide). The gaseous mixture was co-deposited onto a cold CsI window $(T=10 \mathrm{~K})$ mounted on the tip of an APD Cryogenics DE-202A closed-cycle helium refrigerator. Care was taken to keep the guest-to-host ratio in matrices low enough to avoid association.

The matrices were irradiated through the outer $\mathrm{KBr}$ window of the cryostat, with filtered or unfiltered light from a $150 \mathrm{~W}$ xenon arc lamp (Osram XBO 150 W/CR OFR).

The infrared spectra were recorded with $0.5 \mathrm{~cm}^{-1}$ resolution using a Mattson (AR60) Infinity Series FTIR spectrometer equipped with a $\mathrm{KBr}$ beamsplitter and a DTGS detector.

\section{Computational details}

The equilibrium geometries for all studied species were fully optimized at the DFT level of theory with the standard $6-311++G(d, p)$ basis set. The DFT calculations were carried out with the three-parameter density functional (B3LYP) which includes Becke's gradient exchange correction [7], the Lee et al. correlation functional [8] and the Vosko et al. [9] correlation functional. During optimizations no restriction of symmetry was imposed on the initial structure. The<smiles>Cc1ccc(C)cc1</smiles>

Fig. 1. Atom numbering used in the normal mode analysis of 4,6-dimethyl$\alpha$-pyrone.

optimized geometry for 4,6-dimethyl- $\alpha$-pyrone converged to a structure with the planar heavy-atom backbone (Fig. 1).

The geometry optimizations were followed by IR frequency calculations to verify whether the calculated structures are local minima on the potential energy surfaces of the respective systems. For each of the studied species, a set of internal coordinates was defined and the Cartesian force constants were transformed to the internal coordinates space, allowing ordinary normal-coordinate analysis to be performed as described by Schachtschneider [10]. Internal coordinate sets defined for DMAP, its Dewar isomer and the complex between 1,3-dimethyl-cyclobutadiene and $\mathrm{CO}_{2}$ are

Table 1

Internal coordinates used in the normal mode analysis for DMAP (atom numbering as in Fig. 1) ${ }^{\mathrm{a}}$

\begin{tabular}{|c|c|}
\hline$S_{1}=r_{1,2}$ & $v(\mathrm{O} 1-\mathrm{C} 2)$ \\
\hline$S_{2}=r_{2,3}$ & $v(\mathrm{C} 2-\mathrm{C} 3)$ \\
\hline$S_{3}=r_{3,4}$ & $v(\mathrm{C} 3=\mathrm{C} 4)$ \\
\hline$S_{4}=r_{4,5}$ & $v(\mathrm{C} 4-\mathrm{C} 5)$ \\
\hline$S_{5}=r_{5,6}$ & $v(\mathrm{C} 5=\mathrm{C} 6)$ \\
\hline$S_{6}=r_{6,1}$ & $v(\mathrm{C} 6-\mathrm{O} 1)$ \\
\hline$S_{7}=r_{7,2}$ & $v(\mathrm{C} 2=\mathrm{O} 7)$ \\
\hline$S_{8}=r_{8,6}$ & $v(\mathrm{C} 6-\mathrm{C} 8)$ \\
\hline$S_{9}=\left(3^{-1 / 2}\right)\left(r_{9,8}+r_{10,8}+r_{11,8}\right)$ & $v\left(\mathrm{CH}_{3}\right)_{\mathrm{s}}^{1}$ \\
\hline$S_{10}=\left(6^{-1 / 2}\right)\left(2 r_{11,8}-r_{10,8}-r_{9,8}\right)$ & $v\left(\mathrm{CH}_{3}\right)_{\mathrm{as}}^{1^{\prime}}$ \\
\hline$S_{11}=\left(2^{-1 / 2}\right)\left(r_{10,8}-r_{9,8}\right)$ & $v\left(\mathrm{CH}_{3}\right)_{\text {as }}^{1 \prime \prime}$ \\
\hline$S_{12}=r_{12,5}$ & $v(\mathrm{C} 5-\mathrm{H} 12)$ \\
\hline$S_{13}=r_{13,4}$ & $v(\mathrm{C} 4-\mathrm{C} 13)$ \\
\hline$S_{14}=\left(3^{-1 / 2}\right)\left(r_{14,13}+r_{15,13}+r_{16,13}\right)$ & $v\left(\mathrm{CH}_{3}\right)_{\mathrm{s}}^{2}$ \\
\hline$S_{15}=\left(6^{-1 / 2}\right)\left(2 r_{16,13}-r_{15,13}-\mathrm{r}_{14,13}\right)$ & $v\left(\mathrm{CH}_{3}\right)_{\mathrm{as}}^{2 \prime}$ \\
\hline$S_{16}=\left(2^{-1 / 2}\right)\left(r_{15,13}-r_{14,13}\right)$ & $v\left(\mathrm{CH}_{3}\right)_{\mathrm{as}}^{2 \prime \prime}$ \\
\hline$S_{17}=r_{17,3}$ & $v(\mathrm{C} 3-\mathrm{H} 17)$ \\
\hline $\begin{aligned} S_{18}= & \left(6^{-1 / 2}\right)\left(\beta_{6,2,1}-\beta_{1,3,2}+\beta_{2,4,3}-\beta_{3,5,4}\right. \\
& \left.+\beta_{4,6,5}-\beta_{5,1,6}\right)\end{aligned}$ & $\delta$ ring 1 \\
\hline$S_{19}=\left(2^{-1 / 2}\right)\left(\beta_{7,1,2}-\beta_{7,3,2}\right)$ & $\delta(\mathrm{C} 2=\mathrm{O} 7)$ \\
\hline$S_{20}=\left(2^{-1 / 2}\right)\left(\beta_{8,1,6}-\beta_{8,5,6}\right)$ & $\delta(\mathrm{C} 6-\mathrm{C} 8)$ \\
\hline $\begin{aligned} S_{21}= & \left(6^{-1 / 2}\right)\left(\beta_{9,10,8}+\beta_{10,11,8}+\beta_{11,9,8}-\beta_{9,6,8}\right. \\
& \left.-\beta_{10,6,8}-\beta_{11,6,8}\right)\end{aligned}$ & $\delta\left(\mathrm{CH}_{3}\right)_{\mathrm{s}}^{1}$ \\
\hline$S_{22}=\left(6^{-1 / 2}\right)\left(2 \beta_{9,10,8}-\beta_{10,11,8}-\beta_{11,9,8}\right)$ & $\delta\left(\mathrm{CH}_{3}\right)_{\mathrm{as}}^{1^{\prime}}$ \\
\hline$S_{23}=\left(2^{-1 / 2}\right)\left(\beta_{10,11,8}-\beta_{11,9,8}\right)$ & $\delta\left(\mathrm{CH}_{3}\right)_{\text {as }}^{1 \prime \prime}$ \\
\hline$S_{24}=\left(6^{-1 / 2}\right)\left(2 \beta_{11,6,8}-\beta_{10,6,8}-\beta_{9,6,8}\right)$ & $\gamma\left(\mathrm{CH}_{3}\right)_{\mathrm{as}}^{1^{\prime}}$ \\
\hline$S_{25}=\left(2^{-1 / 2}\right)\left(\beta_{10,6,8}-\beta_{9,6,8}\right)$ & $\gamma\left(\mathrm{CH}_{3}\right)_{\mathrm{as}}^{1^{\prime \prime}}$ \\
\hline$S_{26}=\left(2^{-1 / 2}\right)\left(\beta_{12,6,5}-\beta_{12,4,5}\right)$ & $\delta(\mathrm{C} 5-\mathrm{H} 12)$ \\
\hline$S_{27}=\left(2^{-1 / 2}\right)\left(\beta_{13,3,4}-\beta_{13,5,4}\right)$ & $\delta(\mathrm{C} 4-\mathrm{C} 13)$ \\
\hline $\begin{aligned} S_{28}= & \left(6^{-1 / 2}\right)\left(\beta_{14,15,13}+\beta_{15,16,13}+\beta_{16,14,13}\right. \\
& \left.-\beta_{14,4,13}-\beta_{15,4,13}-\beta_{16,4,13}\right)\end{aligned}$ & $\delta\left(\mathrm{CH}_{3}\right)_{\mathrm{s}}^{2}$ \\
\hline$S_{29}=\left(6^{-1 / 2}\right)\left(2 \beta_{14,15,13}-\beta_{15,16,13}-\beta_{16,14,13}\right)$ & $\delta\left(\mathrm{CH}_{3}\right)_{\text {as }}^{2^{\prime}}$ \\
\hline
\end{tabular}


Table 1 (Continued)

\begin{tabular}{rlrl}
\hline$S_{30}=$ & $\left(2^{-1 / 2}\right)\left(\beta_{15,16,13}-\beta_{16,14,13}\right)$ & & $\delta\left(\mathrm{CH}_{3}\right)_{\text {as }}^{2^{\prime \prime}}$ \\
$S_{31}=$ & $\left(2^{-1 / 2}\right)\left(\beta_{17,4,3}-\beta_{17,2,3}\right)$ & & $\delta(\mathrm{C} 3-\mathrm{H} 17)$ \\
$S_{32}=$ & $\left(6^{-1 / 2}\right)\left(2 \beta_{16,4,13}-\beta_{15,4,13}-\beta_{14,4,13}\right)$ & & $\gamma\left(\mathrm{CH}_{3}\right)_{\text {as }}^{2^{\prime}}$ \\
$S_{33}=$ & $\left(2^{-1 / 2}\right)\left(\beta_{15,4,13}-\beta_{14,4,13}\right)$ & & $\gamma\left(\mathrm{CH}_{3}\right)_{\text {as }}^{2^{\prime \prime}}$ \\
$S_{34}=$ & $\left(12^{-1 / 2}\right)\left(2 \beta_{6,2,1}-\beta_{1,3,2}-\beta_{2,4,3}\right.$ & & $\delta$ ring 2 \\
& $\left.+2 \beta_{3,5,4}-\beta_{4,6,5}-\beta_{5,1,6}\right)$ & & \\
$S_{35}=$ & $(1 / 2)\left(\beta_{1,3,2}-\beta_{2,4,3}+\beta_{4,6,5}-\beta_{5,1,6}\right)$ & & $\delta$ ring 3 \\
$S_{36}=$ & $\left(6^{-1 / 2}\right)\left(\tau_{6,1,2,3}-\tau_{1,2,3,4}+\tau_{2,3,4,5}\right.$ & & $\gamma$ ring 1 \\
& $\left.-\tau_{3,4,5,6}+\tau_{4,5,6,1}-\tau_{5,6,1,2}\right)$ & & \\
$S_{37}=$ & $\left(12^{-1 / 2}\right)\left(2 \tau_{6,1,2,3}-\tau_{1,2,3,4}-\tau_{2,3,4,5}\right.$ & & $\gamma$ ring 2 \\
& $\left.+2 \tau_{3,4,5,6}-\tau_{4,5,6,1}-\tau_{5,6,1,2}\right)$ & & \\
$S_{38}=$ & $(1 / 2)\left(\tau_{1,2,3,4}-\tau_{2,3,4,5}+\tau_{4,5,6,1}-\tau_{5,6,1,2}\right)$ & & $\gamma$ ring 3 \\
$S_{39}=$ & $\left(6^{-1 / 2}\right)\left(\tau_{9,8,6,1}+\tau_{9,8,6,5}+\tau_{10,8,6,1}\right.$ & & Twist $(\mathrm{CH})^{1}$ \\
& $\left.+\tau_{10,8,6,5}+\tau_{11,8,6,1}+\tau_{11,8,6,5}\right)$ & & \\
$S_{40}=$ & $\left(6^{-1 / 2}\right)\left(\tau_{14,13,4,3}+\tau_{14,13,4,5}+\tau_{15,13,4,3}\right.$ & & Twist $\left(\mathrm{CH}_{3}\right)^{2}$ \\
& $\left.+\tau_{15,13,4,5}+\tau_{16,13,4,3}+\tau_{16,13,4,5}\right)$ & & \\
$S_{41}=$ & $\gamma_{7,3,2,1}$ & & $\gamma(\mathrm{C} 2=\mathrm{O} 7)$ \\
$S_{42}=$ & $\gamma_{8,1,6,5}$ & & $\gamma(\mathrm{C} 6-\mathrm{C} 8)$ \\
$S_{43}=$ & $\gamma_{12,6,5,4}$ & & $\gamma(\mathrm{C} 5-\mathrm{H} 12)$ \\
$S_{44}=$ & $\gamma_{13,5,4,3}$ & & $\gamma(\mathrm{C} 4-\mathrm{C} 13)$ \\
$S_{45}=$ & $\gamma_{17,4,3,2}$ & & $\gamma(\mathrm{C} 3-\mathrm{H} 17)$ \\
\hline
\end{tabular}

${ }^{\mathrm{a}} r_{i, j}$ is the distance between atoms $A_{i}$ and $A_{j} ; \beta_{i, j, k}$ is the angle between vectors $A_{k} A_{i}$ and $A_{k} A_{j} ; \tau_{i, j, k, l}$ is the dihedral angle between the plane defined by $A_{i}, A_{j}, A_{k}$ and the plane defined by $A_{j}, A_{k}, A_{l}$ atoms; $\gamma_{i, j, k, l}$ is the angle between the vector $A_{k} A_{i}$ and the plane defined by atoms $A_{j}, A_{k}, A_{l}$

\section{Table 2}

Internal coordinates used in the normal mode analysis for DOOBH (atom numbering as in Fig. 3) ${ }^{\mathrm{a}}$

\begin{tabular}{|c|c|}
\hline$S_{1}=r_{1,2}$ & $v(\mathrm{O} 1-\mathrm{C} 2)$ \\
\hline$S_{2}=r_{2,3}$ & $v(\mathrm{C} 2-\mathrm{C} 3)$ \\
\hline$S_{3}=r_{3,4}$ & $v(\mathrm{C} 3-\mathrm{C} 4)$ \\
\hline$S_{4}=r_{4,5}$ & $v(\mathrm{C} 4=\mathrm{C} 5)$ \\
\hline$S_{5}=r_{5,6}$ & $v(\mathrm{C} 5-\mathrm{C} 6)$ \\
\hline$S_{6}=r_{6,1}$ & $v(\mathrm{C} 6-\mathrm{O} 1)$ \\
\hline$S_{7}=r_{3,6}$ & $v(\mathrm{C} 3-\mathrm{C} 6)$ \\
\hline$S_{8}=r_{7,2}$ & $v(\mathrm{C} 2=\mathrm{O} 7)$ \\
\hline$S_{9}=r_{8,6}$ & $v(\mathrm{C} 6-\mathrm{C} 8)$ \\
\hline$S_{10}=\left(3^{-1 / 2}\right)\left(r_{9,8}+r_{10,8}+r_{11,8}\right)$ & $v\left(\mathrm{CH}_{3}\right)_{\mathrm{s}}^{1}$ \\
\hline$S_{11}=\left(6^{-1 / 2}\right)\left(2 r_{10,8}-r_{9,8}-r_{11,8}\right)$ & $v\left(\mathrm{CH}_{3}\right)_{\mathrm{as}}^{1^{\prime}}$ \\
\hline$S_{12}=\left(2^{-1 / 2}\right)\left(r_{9,8}-r_{11,8}\right)$ & $v\left(\mathrm{CH}_{3}\right)_{\mathrm{as}}^{1^{\prime \prime}}$ \\
\hline$S_{13}=r_{12,5}$ & $v(\mathrm{C} 5-\mathrm{H} 12)$ \\
\hline$S_{14}=r_{13,4}$ & $v(\mathrm{C} 4-\mathrm{C} 13)$ \\
\hline$S_{15}=\left(3^{-1 / 2}\right)\left(r_{14,13}+r_{15,13}+r_{16,13}\right)$ & $v\left(\mathrm{CH}_{3}\right)_{\mathrm{s}}^{2}$ \\
\hline$S_{16}=\left(6^{-1 / 2}\right)\left(2 r_{14,13}-r_{15,13}-r_{16,13}\right)$ & $v\left(\mathrm{CH}_{3}\right)_{\mathrm{as}}^{2^{\prime}}$ \\
\hline$S_{17}=\left(2^{-1 / 2}\right)\left(r_{15,13}-r_{16,13}\right)$ & $v\left(\mathrm{CH}_{3}\right)_{\mathrm{as}}^{2 \prime \prime}$ \\
\hline$S_{18}=r_{17,3}$ & $v(\mathrm{C} 3-\mathrm{H} 17)$ \\
\hline$S_{19}=(1 / 2)\left(\beta_{2,6,1}+\beta_{2,6,3}-\beta_{1,3,2}-\beta_{1,3,6}\right)$ & $\delta$ ring 1 \\
\hline$S_{20}=(1 / 2)\left(\beta_{6,4,3}+\beta_{6,4,5}-\beta_{3,5,6}-\beta_{3,5,4}\right)$ & $\delta$ ring 2 \\
\hline$S_{21}=\left(2^{-1 / 2}\right)\left(\beta_{7,1,2}-\beta_{7,3,2}\right)$ & $\delta(\mathrm{C} 2=\mathrm{O} 7)$ \\
\hline$S_{22}=\beta_{8,3,6}$ & $\delta(\mathrm{C} 6-\mathrm{C} 8)$ \\
\hline $\begin{aligned} S_{23}= & \left(6^{-1 / 2}\right)\left(\beta_{9,10,8}+\beta_{10,11,8}+\beta_{11,9,8}\right. \\
& \left.-\beta_{9,6,8}-\beta_{10,6,8}-\beta_{11,6,8}\right)\end{aligned}$ & $\delta\left(\mathrm{CH}_{3}\right)_{\mathrm{s}}^{1}$ \\
\hline$S_{24}=\left(6^{-1 / 2}\right)\left(2 \beta_{11,9,8}-\beta_{10,11,8}-\beta_{9,10,8}\right)$ & $\delta\left(\mathrm{CH}_{3}\right)_{\mathrm{as}}^{1^{\prime}}$ \\
\hline$S_{25}=\left(2^{-1 / 2}\right)\left(\beta_{10,11,8}-\beta_{9,10,8}\right)$ & $\delta\left(\mathrm{CH}_{3}\right)_{\text {as }}^{1^{\prime \prime}}$ \\
\hline$S_{26}=\left(6^{-1 / 2}\right)\left(2 \beta_{10,6,8}-\beta_{9,6,8}-\beta_{11,6,8}\right)$ & $\gamma\left(\mathrm{CH}_{3}\right)_{\text {as }}^{1^{\prime}}$ \\
\hline$S_{27}=\left(2^{-1 / 2}\right)\left(\beta_{9,6,8}-\beta_{11,6,8}\right)$ & $\gamma\left(\mathrm{CH}_{3}\right)_{\mathrm{as}}^{1^{\prime \prime}}$ \\
\hline$S_{28}=\left(2^{-1 / 2}\right)\left(\beta_{12,6,5}-\beta_{12,4,5}\right)$ & $\delta(\mathrm{C} 5-\mathrm{H} 12)$ \\
\hline$S_{29}=\left(2^{-1 / 2}\right)\left(\beta_{13,3,4}-\beta_{13,5,4}\right)$ & $\delta(\mathrm{C} 4-\mathrm{C} 13)$ \\
\hline$S_{30}=\left(6^{-1 / 2}\right)\left(\beta_{14,15,13}+\beta_{15,16,13}+\beta_{16,14,13}\right.$ & $\delta\left(\mathrm{CH}_{3}\right)_{\mathrm{s}}^{2}$ \\
\hline
\end{tabular}

Table 2 (Continued)

\begin{tabular}{|c|c|}
\hline$S_{31}=\left(6^{-1 / 2}\right)\left(2 \beta_{15,16,13}-\beta_{14,15,13}-\beta_{16,14,13}\right)$ & $\delta\left(\mathrm{CH}_{3}\right)_{\mathrm{as}}^{2 \prime}$ \\
\hline$S_{32}=\left(2^{-1 / 2}\right)\left(\beta_{14,15,13}-\beta_{16,14,13}\right)$ & $\delta\left(\mathrm{CH}_{3}\right)_{\mathrm{as}}^{2 \prime \prime}$ \\
\hline$S_{33}=\left(6^{-1 / 2}\right)\left(2 \beta_{14,4,13}-\beta_{15,4,13}-\beta_{16,4,13}\right)$ & $\gamma\left(\mathrm{CH}_{3}\right)_{\mathrm{as}}^{2^{\prime}}$ \\
\hline$S_{34}=\left(2^{-1 / 2}\right)\left(\beta_{15,4,13}-\beta_{16,4,13}\right)$ & $\gamma\left(\mathrm{CH}_{3}\right)_{\mathrm{as}}^{2 \prime \prime}$ \\
\hline$S_{35}=\beta_{17,6,3}$ & $\delta(\mathrm{C} 3-\mathrm{H} 17)$ \\
\hline$S_{36}=(1 / 2)\left(\tau_{2,1,6,3}+\tau_{6,3,2,1}-\tau_{1,6,3,2}-\tau_{3,2,1,6}\right)$ & $\tau$ ring 1 \\
\hline$S_{37}=(1 / 2)\left(\tau_{6,3,4,5}+\tau_{4,5,6,3}-\tau_{5,6,3,4}-\tau_{3,4,5,6}\right)$ & $\tau$ ring 2 \\
\hline$S_{38}=\left(2^{-1 / 2}\right)\left(\tau_{8,6,3,4}+\tau_{8,6,3,2}\right)$ & $\gamma(\mathrm{C} 6-\mathrm{C} 8)$ \\
\hline$S_{39}=\left(2^{-1 / 2}\right)\left(\tau_{17,3,6,1}+\tau_{17,3,6,5}\right)$ & $\gamma(\mathrm{C} 3-\mathrm{H} 17)$ \\
\hline$S_{40}=\left(2^{-1 / 2}\right)\left(\tau_{2,3,6,5}-\tau_{4,3,6,1}\right)$ & $\tau$ butterfly \\
\hline$S_{41}=\left(6^{-1 / 2}\right)\left(\tau_{9,8,6,1}+\tau_{9,8,6,5}+\tau_{10,8,6,1}\right.$ & Twist $\left(\mathrm{CH}_{3}\right)^{1}$ \\
\hline $\begin{aligned} & \left.+\tau_{10,8,6,5}+\tau_{11,8,6,1}+\tau_{11,8,6,5}\right) \\
S_{42}= & \left(6^{-1 / 2}\right)\left(\tau_{14,13,4,3}+\tau_{14,13,4,5}+\tau_{15,13,4,3}\right. \\
& \left.+\tau_{15,13,4,5}+\tau_{16,13,4,3}+\tau_{16,13,4,5}\right)\end{aligned}$ & Twist $\left(\mathrm{CH}_{3}\right)^{2}$ \\
\hline$S_{43}=\gamma_{7,1,2,3}$ & $\gamma(\mathrm{C} 2=\mathrm{O} 7)$ \\
\hline$S_{44}=\gamma_{12,6,5,4}$ & $\gamma(\mathrm{C} 5-\mathrm{H} 12)$ \\
\hline$S_{45}=\gamma_{13,5,4,3}$ & $\gamma(\mathrm{C} 4-\mathrm{C} 13)$ \\
\hline
\end{tabular}

${ }^{\mathrm{a}} r_{i, j}$ is the distance between atoms $A_{i}$ and $A_{j} ; \beta_{i, j, k}$ is the angle between vectors $A_{k} A_{i}$ and $A_{k} A_{j} ; \tau_{i, j, k, l}$ is the dihedral angle between the plane defined by $A_{i}, A_{j}, A_{k}$ and the plane defined by $A_{j}, A_{k}, A_{l}$ atoms; $\gamma_{i, j, k, l}$ is the angle between the vector $A_{k} A_{i}$ and the plane defined by atoms $A_{j}, A_{k}, A_{l}$.

given in Tables 1-3. The calculated harmonic frequencies were also used to assist the analysis of the experimental spectra and to confirm the nature of the stationary points resulting from the calculations (for all structures discussed below no imaginary frequencies were obtained, indicating they correspond to true minima).

All calculations in this work were done using the Gaussian'98 program [11].

\section{Results and discussion}

The IR spectrum of DMAP isolated in an Ar matrix is presented in Fig. 2. This spectrum is compared with the results of the theoretical simulations carried out at the DFT(B3LYP)/6-311++G(d,p) level. The frequencies and intensities of the observed bands and the corresponding calculated values are collected in Table 4 .

During UV $(\lambda>315 \mathrm{~nm})$ irradiation of the matrix, the initial IR spectrum was systematically decreasing, whereas the spectrum of the Dewar valence isomer of DMAP, 1,5-dimethyl-2-oxa-3-oxobicyclo[2.2.0]hex-5-ene (DOOBH; Fig. 3), appeared and was continuously growing (Fig. 4). The main spectral indication of the photoproduction of DOOBH was the strong band at $1837.7 \mathrm{~cm}^{-1}$ (Ar), which corresponds to the $\nu \mathrm{C}=\mathrm{O}$ vibration of this species. The high frequency of this $\nu \mathrm{C}=\mathrm{O}$ band is typical for carbonyl groups directly attached to a small, four-membered ring. The general rule, saying that the smaller the ring the higher is the $\nu \mathrm{C}=\mathrm{O}$ frequency, is fulfilled in the case of $\alpha$-pyrones. Analogously, the $\nu \mathrm{C}=\mathrm{O}$ band of the Dewar isomer of 3-methyl-4(3H)-pyrimidinone was observed at $1784.0 \mathrm{~cm}^{-1}(\mathrm{Ar})$, whereas the $\nu \mathrm{C}=\mathrm{O}$ band of the normal 

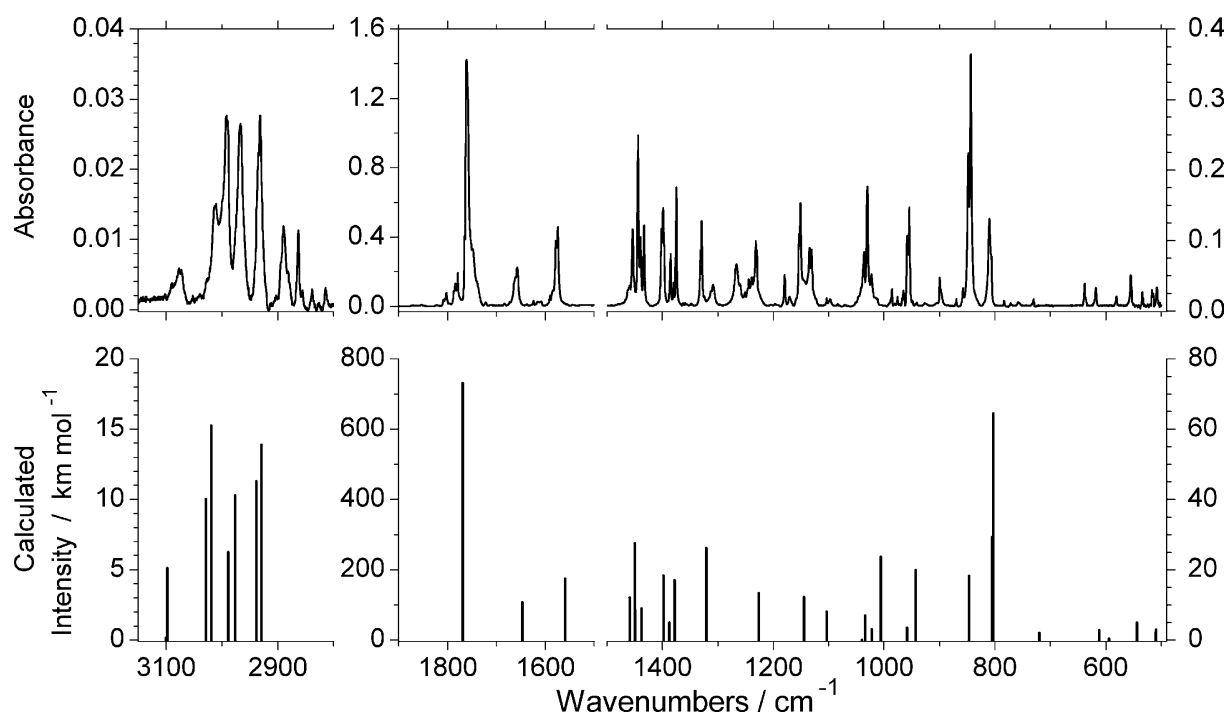

Fig. 2. Comparison of the experimental IR spectrum of DMAP monomers isolated in Ar matrix $(10 \mathrm{~K})$ with the spectrum of the compound calculated at the DFT(B3LYP)/6-311++G(d,p) level. Theoretical frequencies were scaled using a factor equal to 0.978 (except for the $\mathrm{CH}$ stretching region, where the factor 0.968 was used). Note the change of ordinate scale at $1500 \mathrm{~cm}^{-1}$.

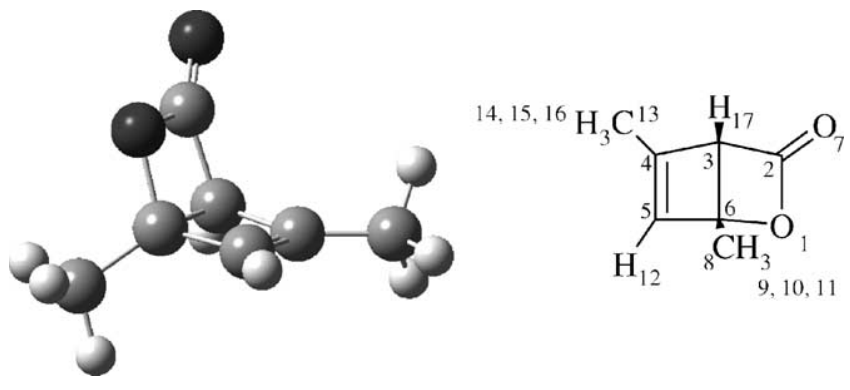

Fig. 3. Optimized structure and atom numbering of the Dewar valence isomer $(\mathrm{DOOBH})$.

isomer of 3-methyl-4(3H)-pyrimidinone was observed at significantly lower frequency $1709.0 \mathrm{~cm}^{-1}(\mathrm{Ar})[12]$.

The progress of the UV $(\lambda>315 \mathrm{~nm})$ induced photoreaction is shown in Fig. 4. Some amount of the open-ring ketene derivative [13] of DMAP was also created, as it can be concluded from the appearance of the characteristic ketene IR band at $2128.9 \mathrm{~cm}^{-1}$. At the final stage of the observed photoreaction (after $523 \mathrm{~min}$ of irradiation) about $90 \%$ of the initial material was converted into DOOBH, while the total amount of the open-ring ketene could be estimated to be ca. $5 \%$ of the main photoproduct only. ${ }^{1}$

Having the IR spectra recorded at different stages of the photoreaction it was then possible to unequivocally identify the bands due to DOOBH. The experimental and calculated spectra for this main photoproduct are compared in Fig. 5, showing a good general agreement. The proposed band assignments are given in Table 5. The agreement between the

\footnotetext{
${ }^{1}$ The relative amounts of DOOBH and open-ring ketene photoproducts were estimated from the ratio of the observed integral intensities of the features around 1850 and $2130 \mathrm{~cm}^{-1}$, respectively, reduced by the corresponding calculated intensities for these species.
}

experimental and theoretical data is particularly good in the frequency range below $1000 \mathrm{~cm}^{-1}$, where the most intense experimental bands at $827.4,783.6$ and $509.3 \mathrm{~cm}^{-1}$ are very well reproduced by the theoretical calculations, which

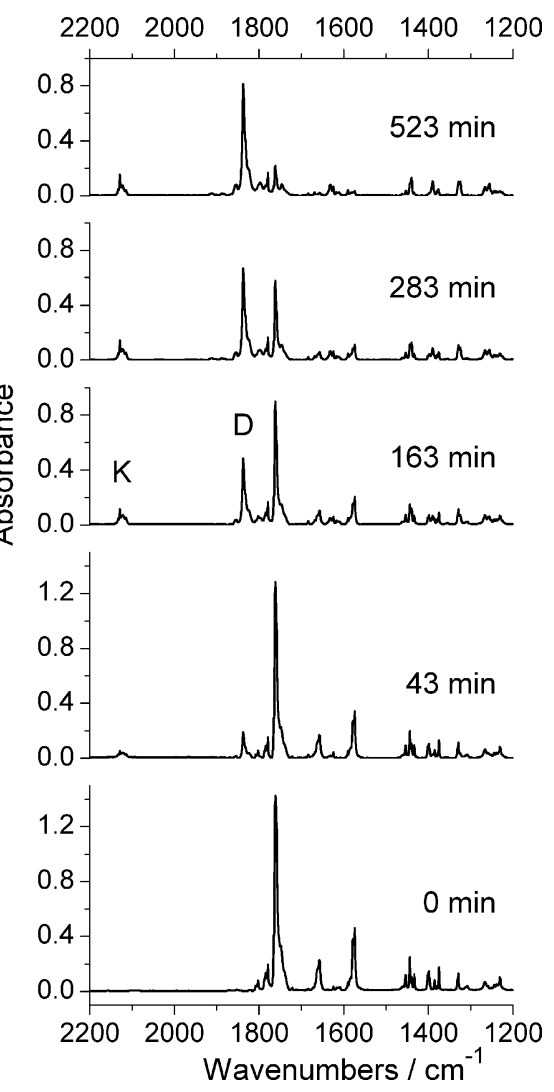

Fig. 4. Progress of the photoreaction induced by UV $(\lambda>315 \mathrm{~nm})$ irradiation of DMAP isolated in Ar matrix $(10 \mathrm{~K})$. K: open-ring conjugated aldehyde-ketene, D: Dewar valence isomer (DOOBH). 
Table 3

Internal coordinates used in the normal mode analysis for the $\mathrm{DMCB}$ stacked to $\mathrm{CO}_{2}$ (atom numbering as in Fig. 6)

\begin{tabular}{|c|c|}
\hline$S_{1}=\left(2^{-1 / 2}\right)\left(r_{1,2}+r_{3,4}\right)$ & $v(\mathrm{C}=\mathrm{C})_{\mathrm{s}}$ \\
\hline$S_{2}=\left(2^{-1 / 2}\right)\left(r_{1,2}-r_{3,4}\right)$ & $\nu(\mathrm{C}=\mathrm{C})_{\mathrm{as}}$ \\
\hline$S_{3}=\left(2^{-1 / 2}\right)\left(r_{2,3}+r_{1,4}\right)$ & $\nu(\mathrm{C}-\mathrm{C})_{\mathrm{S}}$ \\
\hline$S_{4}=\left(2^{-1 / 2}\right)\left(r_{2,3}-r_{1,4}\right)$ & $v(\mathrm{C}-\mathrm{C})_{\mathrm{as}}$ \\
\hline$S_{5}=(1 / 2)\left(r_{4,5}+r_{2,7}\right)$ & $\nu(\mathrm{C}-\mathrm{H})_{\mathrm{s}}$ \\
\hline$S_{6}=(1 / 2)\left(r_{4,5}-r_{2,7}\right)$ & $v(\mathrm{C}-\mathrm{H})_{\text {as }}$ \\
\hline$S_{7}=(1 / 2)\left(r_{3,6}+r_{1,8}\right)$ & $v\left(\mathrm{C}-\mathrm{CH}_{3}\right)_{\mathrm{s}}$ \\
\hline$S_{8}=(1 / 2)\left(r_{3,6}-r_{1,8}\right)$ & $v\left(\mathrm{C}-\mathrm{CH}_{3}\right)_{\mathrm{as}}$ \\
\hline$S_{9}=\left(6^{-1 / 2}\right)\left(r_{9,6}+r_{10,6}+r_{11,6}+r_{12,8}+r_{13,8}+r_{14,8}\right)$ & $v\left(\mathrm{CH}_{3}\right)_{\mathrm{s}}$ \\
\hline$S_{10}=\left(6^{-1 / 2}\right)\left(r_{9,6}+r_{10,6}+r_{11,6}-r_{12,8}-r_{13,8}-r_{14,8}\right)$ & $v\left(\mathrm{CH}_{3}\right)_{\mathrm{s}}^{\prime}$ \\
\hline$S_{11}=\left(12^{-1 / 2}\right)\left(2 r_{9,6}-r_{10,6}-r_{11,6}+2 r_{12,8}-r_{13,8}-r_{14,8}\right)$ & $v\left(\mathrm{CH}_{3}\right)_{\mathrm{as}}$ \\
\hline$S_{12}=\left(12^{-1 / 2}\right)\left(2 r_{9,6}-r_{10,6}-r_{11,6}-2 r_{12,8}+r_{13,8}+r_{14,8}\right)$ & $v\left(\mathrm{CH}_{3}\right)_{\mathrm{as}}^{\prime}$ \\
\hline$S_{13}=(1 / 2)\left(r_{10,6}-r_{11,6}+r_{13,8}-r_{14,8}\right)$ & $v\left(\mathrm{CH}_{3}\right)_{\mathrm{as}}^{\prime \prime}$ \\
\hline$S_{14}=(1 / 2)\left(r_{10,6}-r_{11,6}-r_{13,8}+r_{14,8}\right)$ & $v\left(\mathrm{CH}_{3}\right)_{\mathrm{as}}^{\prime \prime \prime}$ \\
\hline$S_{15}=(1 / 2)\left(\beta_{2,4,1}+\beta_{2,4,3}-\beta_{1,3,2}-\beta_{1,3,4}\right)$ & $\delta$ ring \\
\hline$S_{16}=(1 / 2)\left(\beta_{5,1,4}-\beta_{5,3,4}+\beta_{7,3,2}-\beta_{7,1,2}\right)$ & $\delta(\mathrm{C}-\mathrm{H})_{\mathrm{s}}$ \\
\hline$S_{17}=(1 / 2)\left(\beta_{6,4,3}-\beta_{6,2,3}+\beta_{8,2,1}-\beta_{8,4,1}\right)$ & $\delta\left(\mathrm{C}-\mathrm{CH}_{3}\right)_{\mathrm{S}}$ \\
\hline$S_{18}=(1 / 2)\left(\beta_{5,1,4}-\beta_{5,3,4}-\beta_{7,3,2}+\beta_{7,1,2}\right)$ & $\delta(\mathrm{C}-\mathrm{H})_{\mathrm{as}}$ \\
\hline$S_{19}=(1 / 2)\left(\beta_{6,4,3}-\beta_{6,2,3}-\beta_{8,2,1}+\beta_{8,4,1}\right)$ & $\delta\left(\mathrm{C}-\mathrm{CH}_{3}\right)_{\mathrm{as}}$ \\
\hline$S_{20}=\left(12^{-1 / 2}\right)\left(\beta_{9,10,6}+\beta_{10,11,6}+\beta_{11,9,6}-\beta_{9,3,6}-\beta_{10,3,6}-\beta_{11,3,6}\right.$ & $\delta\left(\mathrm{CH}_{3}\right)_{\mathrm{s}}$ \\
\hline $\begin{aligned} S_{21}= & \left(12^{-1 / 2}\right)\left(\beta_{9,10,6}+\beta_{10,11,6}+\beta_{11,9,6}-\beta_{9,3,6}-\beta_{10,3,6}-\beta_{11,3,6}\right. \\
& \left.-\beta_{12,13,8}-\beta_{13,14,8}-\beta_{14,12,8}+\beta_{12,1,8}+\beta_{13,1,8}+\beta_{14,1,8}\right)\end{aligned}$ & $\delta\left(\mathrm{CH}_{3}\right)_{\mathrm{s}}^{\prime}$ \\
\hline$S_{22}=\left(12^{-1 / 2}\right)\left(2 \beta_{9,10,6}-\beta_{10,11,6}-\beta_{11,9,6}+2 \beta_{12,13,8}-\beta_{13,14,8}-\beta_{14,12,8}\right)$ & $\delta\left(\mathrm{CH}_{3}\right)_{\text {as }}$ \\
\hline$S_{23}=\left(12^{-1 / 2}\right)\left(2 \beta_{9,10,6}-\beta_{10,11,6}-\beta_{11,9,6}-2 \beta_{12,13,8}+\beta_{13,14,8}+\beta_{14,12,8}\right)$ & $\delta\left(\mathrm{CH}_{3}\right)_{\mathrm{as}}^{\prime}$ \\
\hline$S_{24}=(1 / 2)\left(\beta_{10,11,6}-\beta_{11,9,6}+\beta_{13,14,8}-\beta_{14,12,8}\right)$ & $\delta\left(\mathrm{CH}_{3}\right)_{\text {as }}^{\prime \prime}$ \\
\hline$S_{25}=(1 / 2)\left(\beta_{10,11,6}-\beta_{11,9,6}-\beta_{13,14,8}+\beta_{14,12,8}\right)$ & $\delta\left(\mathrm{CH}_{3}\right)_{\mathrm{as}}^{\prime \prime \prime}$ \\
\hline$S_{26}=\left(12^{-1 / 2}\right)\left(2 \beta_{9,3,6}-\beta_{10,3,6}-\beta_{11,3,6}+2 \beta_{12,1,8}-\beta_{13,1,8}-\beta_{14,1,8}\right)$ & $\gamma\left(\mathrm{CH}_{3}\right)_{\text {as }}$ \\
\hline$S_{27}=\left(12^{-1 / 2}\right)\left(2 \beta_{9,3,6}-\beta_{10,3,6}-\beta_{11,3,6}-2 \beta_{12,1,8}+\beta_{13,1,8}+\beta_{14,1,8}\right)$ & $\gamma\left(\mathrm{CH}_{3}\right)_{\mathrm{as}}^{\prime}$ \\
\hline$S_{28}=(1 / 2)\left(\beta_{10,3,6}-\beta_{11,3,6}+\beta_{13,1,8}-\beta_{14,1,8}\right)$ & $\gamma\left(\mathrm{CH}_{3}\right)_{\mathrm{as}}^{\prime \prime}$ \\
\hline$S_{29}=(1 / 2)\left(\beta_{10,3,6}-\beta_{11,3,6}-\beta_{13,1,8}+\beta_{14,1,8}\right)$ & $\gamma\left(\mathrm{CH}_{3}\right)_{\mathrm{as}}^{\prime \prime \prime}$ \\
\hline$S_{30}=\left(2^{-1 / 2}\right)\left(\tau_{1,2,3,4}+\tau_{3,4,1,2}\right)$ & $\tau$ ring \\
\hline$S_{31}=\left(2^{-1 / 2}\right)\left(\tau_{4,3,6,9}+\tau_{2,1,8,12}\right)$ & $\tau\left(\mathrm{C}-\mathrm{CH}_{3}\right)$ \\
\hline$S_{32}=\left(2^{-1 / 2}\right)\left(\tau_{4,3,6,9}-\tau_{2,1,8,12}\right)$ & $\tau\left(\mathrm{C}-\mathrm{CH}_{3}\right)^{\prime}$ \\
\hline$S_{33}=\left(2^{-1 / 2}\right)\left(\gamma_{5,1,4,3}+\gamma_{7,3,2,1}\right)$ & $\gamma(\mathrm{C}-\mathrm{H})_{\mathrm{s}}$ \\
\hline$S_{34}=\left(2^{-1 / 2}\right)\left(\gamma_{5,1,4,3}-\gamma_{7,3,2,1}\right)$ & $\gamma(\mathrm{C}-\mathrm{H})_{\text {as }}$ \\
\hline$S_{35}=\left(2^{-1 / 2}\right)\left(\gamma_{6,4,3,2}+\gamma_{8,2,1,4}\right)$ & $\gamma\left(\mathrm{C}-\mathrm{CH}_{3}\right)_{\mathrm{s}}$ \\
\hline$S_{36}=\left(2^{-1 / 2}\right)\left(\gamma_{6,4,3,2}-\gamma_{8,2,1,4}\right)$ & $\gamma\left(\mathrm{C}-\mathrm{CH}_{3}\right)_{\text {as }}$ \\
\hline$S_{37}=\left(2^{-1 / 2}\right)\left(r_{15,16}+r_{15,17}\right)$ & $v\left(\mathrm{CO}_{2}\right)_{\mathrm{s}}$ \\
\hline$S_{38}=\left(2^{-1 / 2}\right)\left(r_{15,16}-r_{15,17}\right)$ & $v\left(\mathrm{CO}_{2}\right)_{\mathrm{as}}$ \\
\hline$S_{39}=\operatorname{lin} 1_{17,16,15,3}$ & $\delta\left(\mathrm{CO}_{2}\right)_{\mathrm{s}}$ \\
\hline$S_{40}=\operatorname{lin} 2_{17,16,15,3}$ & $\delta\left(\mathrm{CO}_{2}\right)_{\mathrm{as}}$ \\
\hline$S_{41}=\left(2^{-1 / 2}\right)\left(\beta_{4,16,1}+\beta_{2,17,3}\right)$ & $\mathrm{CO}_{2}$-ring twist \\
\hline$S_{42}=\left(2^{-1 / 2}\right)\left(r_{4,17}-r_{2,16}\right)$ & $\mathrm{CO}_{2}$-ring wag \\
\hline$S_{43}=\left(2^{-1 / 2}\right)\left(r_{3,17}+r_{1,16}\right)$ & $\mathrm{CO}_{2}$-ring symmetric stretching \\
\hline$S_{44}=\left(2^{-1 / 2}\right)\left(r_{3,17}-r_{1,16}\right)$ & $\mathrm{CO}_{2}$-ring asymmetric stretching \\
\hline$S_{45}=\left(2^{-1 / 2}\right)\left(\beta_{4,16,1}-\beta_{2,17,3}\right)$ & $\mathrm{CO}_{2}$-ring parallel shift \\
\hline
\end{tabular}

${ }^{\mathrm{a}} r_{i, j}$ is the distance between atoms $A_{i}$ and $A_{j} ; \beta_{i, j, k}$ is the angle between vectors $A_{k} A_{i}$ and $A_{k} A_{j} ; \tau_{i, j, k, l}$ is the dihedral angle between the plane defined by $A_{i}, A_{j}, A_{k}$ and the plane defined by $A_{j}, A_{k}, A_{l}$ atoms; $\gamma_{i, j, k, l}$ is the angle between the vector $A_{k} A_{i}$ and the plane defined by atoms $A_{j}, A_{k}$, $A_{l}$; lin $1_{i, j, k, l}$ collinear bending $A_{i}-A_{j}-A_{k}$ distorted in the plane of $A_{i} A_{j} A_{l} ; \operatorname{lin} 2_{i, j, k, l}$ linear bending $A_{i}-A_{k}-A_{j}$ distorted perpendicular to the plane $A_{i} A_{j} A_{l}$.

predict these bands at $828.0,761.9$ and $503.6 \mathrm{~cm}^{-1}$, respectively. To the best of our knowledge, this is the first positive identification of a Dewar form of an $\alpha$-pyrone based on the analysis of the whole mid-infrared region of its spectrum.

Norrish type I, $\alpha$-cleavage processes leading to the open-ring ketene species are believed $[14,15]$ to originate from the excited states with $n \pi^{*}$ character, whereas formation of Dewar isomers should proceed starting from the excited $\pi \pi^{*}$ state. In $\alpha$-pyrones, which are six-membered ring compounds with the double bond of the carbonyl group linearly conjugated with two double bonds in the ring, the lowest excited singlet state has $n \pi^{*}$ character [3]. Hence, the $n \pi^{*}$-type photochemistry should be favored for such compounds, especially when they are free of any substituents. On the other hand, methyl substituents attached to the ring lead to an effective extension of the $\pi$-electron system of a molecule, by hyperconjugation. As a consequence, the energy gap between the ground state and the $\pi \pi^{*}$ excited state should diminish and the gap between the ground and the $n \pi^{*}$ state should increase $[3,16]$. For compounds 
Table 4

Observed and calculated vibrational frequencies, intensities and potential energy distributions (PED) for DMAP monomer (frequencies $(v)$ in $\mathrm{cm}^{-1}$, theoretical intensities $(I)$ in $\mathrm{km} \mathrm{mol}^{-1}$ )

\begin{tabular}{|c|c|c|c|c|c|}
\hline \multicolumn{2}{|c|}{$\begin{array}{l}\text { Observed (infrared, Ar } \\
\text { matrix, } T=10 \mathrm{~K} \text { ) }\end{array}$} & \multicolumn{2}{|c|}{$\begin{array}{l}\text { Calculated } \\
(\mathrm{B} 3 \mathrm{LYP} / 6-311++\mathrm{G}(\mathrm{d}, \mathrm{p}))\end{array}$} & \multirow[t]{2}{*}{ Symmetry } & \multirow[t]{2}{*}{$\operatorname{PED}^{\mathrm{a}}(\%)$} \\
\hline$v$ & $I^{\mathrm{b}}$ & $\nu^{\mathrm{c}}$ & $I$ & & \\
\hline & & 3100.5 & 0.2 & $\mathrm{~A}^{\prime}$ & $v(\mathrm{C} 3-\mathrm{H} 17)(91.0)$ \\
\hline 3074.7 & 3.0 & 3098.0 & 5.1 & $\mathrm{~A}^{\prime}$ & $v(\mathrm{C} 5-\mathrm{H} 12)(90.9)$ \\
\hline 3012.5 & 6.7 & 3029.0 & 10.0 & $\mathrm{~A}^{\prime}$ & $v\left(\mathrm{CH}_{3}\right)_{\text {as }}^{1^{\prime}}(96.8)$ \\
\hline \multirow[t]{2}{*}{2991.8} & 14.9 & 3019.5 & 15.3 & $\mathrm{~A}^{\prime}$ & $v\left(\mathrm{CH}_{3}\right)_{\mathrm{as}}^{2^{\prime}}(95.8)$ \\
\hline & & 2989.1 & 6.3 & $\mathrm{~A}^{\prime \prime}$ & $v\left(\mathrm{CH}_{3}\right)_{\mathrm{as}}^{1^{\prime \prime}}(100.3)$ \\
\hline 2967.1 & 13.9 & 2976.6 & 10.3 & $\mathrm{~A}^{\prime \prime}$ & $v\left(\mathrm{CH}_{3}\right)_{\mathrm{as}}^{2^{\prime \prime}}(100.3)$ \\
\hline 2935.2 & & 2938.1 & 11.3 & $\mathrm{~A}^{\prime}$ & $v\left(\mathrm{CH}_{3}\right)_{\mathrm{s}}^{1}(96.8)$ \\
\hline 2932.0 & 11.1 & 2929.6 & 13.9 & $\mathrm{~A}^{\prime}$ & $v\left(\mathrm{CH}_{3}\right)_{\mathrm{s}}^{2}(95.7)$ \\
\hline 1802.4 & 22.5 & & & & \\
\hline \multicolumn{6}{|l|}{1783.7} \\
\hline 1778.6 & 60.1 & & & & \\
\hline 1761.3 & 626.3 & 1768.8 & 730.6 & $\mathrm{~A}^{\prime}$ & $v(\mathrm{O} 7=\mathrm{C} 2)(81.2)$ \\
\hline \multicolumn{6}{|l|}{1661.5} \\
\hline 1657.4 & 106.6 & 1647.2 & 107.5 & $\mathrm{~A}^{\prime}$ & $v(\mathrm{C} 6=\mathrm{C} 5)(38.8)+v(\mathrm{C} 4=\mathrm{C} 3)(25.4)$ \\
\hline \multicolumn{6}{|l|}{1578.3} \\
\hline 1574.0 & 161.2 & 1559.1 & 174.6 & $\mathrm{~A}^{\prime}$ & $v(\mathrm{C} 4=\mathrm{C} 3)(38.8)+v(\mathrm{C} 6=\mathrm{C} 5)$ \\
\hline 1453.9 & 19.5 & 1458.8 & 12.1 & $\mathrm{~A}^{\prime}$ & $\delta\left(\mathrm{CH}_{3}\right)_{\mathrm{as}}^{1^{\prime}}(49.1)+\delta\left(\mathrm{CH}_{3}\right)_{\mathrm{as}}^{2^{\prime}}(22.6)$ \\
\hline 1444.2 & 27.7 & 1450.1 & 27.5 & $\mathrm{~A}^{\prime}$ & $\delta\left(\mathrm{CH}_{3}\right)_{\text {as }}^{2^{\prime}}(59.4)+\delta\left(\mathrm{CH}_{3}\right)_{\text {as }}^{1^{\prime}}(24.5)$ \\
\hline 1439.4 & 7.8 & 1449.0 & 8.6 & $\mathrm{~A}^{\prime \prime}$ & $\delta\left(\mathrm{CH}_{3}\right)_{\text {as }}^{2 \prime \prime}(92.1)$ \\
\hline 1433.3 & 11.8 & 1437.6 & 9.0 & $\mathrm{~A}^{\prime \prime}$ & $\delta\left(\mathrm{CH}_{3}\right)_{\text {as }}^{1^{\prime \prime}}(91.2)$ \\
\hline 1401.9 & 31.3 & & & & \\
\hline 1399.1 & & 1398.4 & 18.3 & $\mathrm{~A}^{\prime}$ & $\begin{array}{l}\delta\left(\mathrm{CH}_{3}\right)_{\mathrm{s}}^{2}(18.8)+v(\mathrm{C} 5-\mathrm{C} 4)(17.6)+\delta\left(\mathrm{CH}_{3}\right)_{\text {as }}^{1^{\prime}}(12.7)+ \\
\delta(\mathrm{C} 3-\mathrm{H} 17)(11.1)\end{array}$ \\
\hline 1385.3 & 7.5 & 1387.2 & 5.0 & $\mathrm{~A}^{\prime}$ & $\delta\left(\mathrm{CH}_{3}\right)_{\mathrm{s}}^{1}(89.1)$ \\
\hline 1379.6 & 1.9 & & & & \\
\hline 1374.7 & 16.7 & 1378.0 & 17.0 & $\mathrm{~A}^{\prime}$ & $\delta\left(\mathrm{CH}_{3}\right)_{\mathrm{s}}^{2}(72.8)$ \\
\hline 1331.7 & 21.5 & & & & \\
\hline 1329.1 & & 1320.8 & 26.2 & $\mathrm{~A}^{\prime}$ & $\begin{array}{l}\delta(\mathrm{C} 5-\mathrm{H} 12)(23.5)+v(\mathrm{O} 1-\mathrm{C} 6)(15.7)+v(\mathrm{C} 3-\mathrm{C} 2)(11.2)+ \\
\delta(\mathrm{C} 3-\mathrm{H} 17)(9.8)\end{array}$ \\
\hline 1308.8 & 10.3 & & & & \\
\hline 1266.7 & 24.4 & & & & \\
\hline 1251.0 & Weak & & & & \\
\hline 1244.3 & 4.9 & & & & \\
\hline \multicolumn{6}{|l|}{1239.1} \\
\hline 1231.7 & 30.2 & 1226.3 & 13.3 & $\mathrm{~A}^{\prime}$ & $\delta(\mathrm{C} 3-\mathrm{H} 17)(38.9)+v(\mathrm{C} 8-\mathrm{C} 6)(14.0)+\delta(\mathrm{C} 5-\mathrm{H} 12)(11.3)$ \\
\hline \multicolumn{6}{|r|}{$x^{2}$} \\
\hline 1179.6 & 6.0 & & & & \\
\hline 1170.7 & 7.3 & & & & \\
\hline 1151.2 & 41.3 & 1144.9 & 12.3 & $\mathrm{~A}^{\prime}$ & $\begin{array}{l}\delta(\mathrm{C} 5-\mathrm{H} 12)(32.1)+v(\mathrm{C} 4-\mathrm{C} 13)(16.2)+\delta(\mathrm{C} 3-\mathrm{H} 17)(15.0)+ \\
v(\mathrm{O} 1-\mathrm{C} 6)(10.7)\end{array}$ \\
\hline 1134.7 & 32.7 & 1103.8 & 8.1 & $\mathrm{~A}^{\prime}$ & $v(\mathrm{C} 3-\mathrm{C} 2)(42.1)$ \\
\hline \multicolumn{6}{|l|}{1130.8} \\
\hline 1103.7 & 0.8 & & & & \\
\hline \multirow[t]{2}{*}{1097.7} & 2.2 & & & & \\
\hline & & 1039.8 & 0.04 & $\mathrm{~A}^{\prime \prime}$ & $\gamma\left(\mathrm{CH}_{3}\right)_{\text {as }}^{1^{\prime \prime}}(47.5)+\gamma\left(\mathrm{CH}_{3}\right)_{\mathrm{as}}^{2 \prime \prime}(30.5)$ \\
\hline 1036.3 & 11.1 & 1034.2 & 7.0 & $\mathrm{~A}^{\prime \prime}$ & $\gamma\left(\mathrm{CH}_{3}\right)_{\mathrm{as}}^{2 \prime \prime}(45.6)+\gamma\left(\mathrm{CH}_{3}\right)_{\mathrm{as}}^{1^{\prime \prime}}(30.5)$ \\
\hline 1030.4 & 41.4 & 1005.8 & 23.7 & $\mathrm{~A}^{\prime}$ & $\gamma\left(\mathrm{CH}_{3}\right)_{\mathrm{as}}^{2^{\prime}}(36.1)+v(\mathrm{O} 1-\mathrm{C} 6)(19.7)+\delta \operatorname{ring} 1(9.6)$ \\
\hline 1023.1 & 4.0 & 1022.2 & 3.1 & $\mathrm{~A}^{\prime}$ & $\gamma\left(\mathrm{CH}_{3}\right)_{\mathrm{as}}^{1^{\prime}}(53.0)+\gamma\left(\mathrm{CH}_{3}\right)_{\mathrm{as}}^{2^{\prime}}(14.9)$ \\
\hline 985.9 & 4.2 & & & & \\
\hline 976.0 & 2.4 & & & & \\
\hline 965.5 & 4.8 & 958.7 & 3.5 & $\mathrm{~A}^{\prime}$ & $\delta \operatorname{ring} 1(29.6)+v(\mathrm{C} 5-\mathrm{C} 4)(29.2)+\gamma\left(\mathrm{CH}_{3}\right)_{\text {as }}^{2^{\prime}}(19.2)$ \\
\hline 958.5 & 30.0 & & & & \\
\hline 954.5 & & 943.3 & 19.9 & $\mathrm{~A}^{\prime}$ & $v(\mathrm{C} 8-\mathrm{C} 6)(22.9)+v(\mathrm{C} 13-\mathrm{C} 4)(22.6)+v(\mathrm{O} 1-\mathrm{C} 6)(17.8)$ \\
\hline 899.7 & 6.7 & & & & \\
\hline 869.2 & 0.7 & & & & \\
\hline 857.9 & 2.3 & & & & \\
\hline 848.2 & 29.3 & 846.9 & 18.3 & $\mathrm{~A}^{\prime \prime}$ & $\gamma(\mathrm{C} 3-\mathrm{H} 17)(90.9)+\gamma(\mathrm{C} 2=\mathrm{O} 7)$ \\
\hline 843.6 & 58.4 & 803.0 & 64.5 & $\mathrm{~A}^{\prime}$ & $v(\mathrm{C} 2-\mathrm{O} 1)(55.0)+\delta \operatorname{ring} 1(13.5)$ \\
\hline 810.9 & 33.3 & 804.8 & 29.3 & $\mathrm{~A}^{\prime \prime}$ & $\gamma(\mathrm{C} 5-\mathrm{H} 12)(100.1)$ \\
\hline
\end{tabular}


Table 4 (Continued)

\begin{tabular}{|c|c|c|c|c|c|}
\hline \multicolumn{2}{|c|}{$\begin{array}{l}\text { Observed (infrared, Ar } \\
\text { matrix, } T=10 \mathrm{~K} \text { ) }\end{array}$} & \multicolumn{2}{|c|}{$\begin{array}{l}\text { Calculated } \\
(\text { B3LYP/6-311++G(d,p)) }\end{array}$} & \multirow[t]{2}{*}{ Symmetry } & \multirow[t]{2}{*}{$\operatorname{PED}^{\mathrm{a}}(\%)$} \\
\hline$v$ & $I^{\mathrm{b}}$ & $v^{\mathrm{c}}$ & $I$ & & \\
\hline 783.4 & 0.8 & & & & \\
\hline 757.9 & 0.5 & & & & \\
\hline 730.2 & 1.4 & 719.8 & 2.1 & $\mathrm{~A}^{\prime \prime}$ & $\gamma(\mathrm{C} 2=\mathrm{O} 7)(60.9)+\gamma$ ring 1 (43.8) \\
\hline 638.2 & 6.2 & & & & \\
\hline 617.8 & 5.0 & 611.5 & 2.9 & $\mathrm{~A}^{\prime \prime}$ & $\begin{array}{l}\gamma \text { ring } 1(24.7)+\gamma(\mathrm{C} 4-\mathrm{C} 13)(18.0)+\gamma \operatorname{ring} 3(17.6) \\
+\gamma(\mathrm{C} 6-\mathrm{C} 8)(17.0)+\gamma(\mathrm{C} 2=\mathrm{O} 7)(15.9)\end{array}$ \\
\hline 580.8 & 2.1 & 594.1 & 0.3 & $\mathrm{~A}^{\prime}$ & $\begin{array}{l}\delta \text { ring } 1(17.9)+v(\mathrm{C} 2-\mathrm{O} 1)(13.4)+\delta \text { ring } 3(13.0) \\
+v(\mathrm{C} 13-\mathrm{C} 4)(11.5)\end{array}$ \\
\hline 554.1 & 7.0 & 543.8 & 5.0 & $\mathrm{~A}^{\prime}$ & $\delta(\mathrm{C} 2=\mathrm{O} 7)(32.1)+\delta$ ring $3(21.3)+v(\mathrm{C} 8-\mathrm{C} 6)(9.8)$ \\
\hline 534.4 & 1.8 & & & & \\
\hline 516.7 & 2.7 & 509.6 & 2.3 & $\mathrm{~A}^{\prime}$ & $\delta$ ring $3(44.0)+\delta(\mathrm{C} 2=\mathrm{O} 7)(18.8)$ \\
\hline 508.0 & 3.4 & 509.1 & 2.9 & $\mathrm{~A}^{\prime \prime}$ & $\gamma(\mathrm{C} 6-\mathrm{C} 8)(35.1)+\gamma(\mathrm{C} 4-\mathrm{C} 13)(34.6)+\gamma \operatorname{ring} 2(20.8)$ \\
\hline \multirow[t]{8}{*}{472.1} & 2.5 & 464.7 & 0.9 & $\mathrm{~A}^{\prime}$ & $\delta$ ring $2(76.2)$ \\
\hline & & 317.5 & 1.1 & $\mathrm{~A}^{\prime}$ & $\delta(\mathrm{C} 4-\mathrm{C} 13)(33.5)+\delta(\mathrm{C} 6-\mathrm{C} 8)(23.1)+\delta(\mathrm{C} 2=\mathrm{O} 7)(20.0)$ \\
\hline & & 266.4 & 0.6 & $\mathrm{~A}^{\prime}$ & $\delta(\mathrm{C} 6-\mathrm{C} 8)(43.2)+\delta(\mathrm{C} 4-\mathrm{C} 13)(37.8)$ \\
\hline & & 201.6 & 2.4 & $\mathrm{~A}^{\prime \prime}$ & $\gamma$ ring $2(76.2)+$ twist $\left(\mathrm{CH}_{3}\right)^{2}(10.6)$ \\
\hline & & 179.8 & 0.8 & $\mathrm{~A}^{\prime \prime}$ & Twist $\left(\mathrm{CH}_{3}\right)^{1}(39.7)+\gamma$ ring $3(35.0)+\gamma(\mathrm{C} 4-\mathrm{C} 13)$ \\
\hline & & 150.0 & 0.1 & $\mathrm{~A}^{\prime \prime}$ & $\begin{array}{l}\gamma \text { ring } 1(45.7)+\gamma \operatorname{ring} 2(23.8)+\gamma(\mathrm{C} 6-\mathrm{C} 8)(13.8)+\text { twist } \\
\left(\mathrm{CH}_{3}\right)^{2}(9.8)+\gamma \operatorname{ring} 3(9.5)\end{array}$ \\
\hline & & 130.6 & 1.2 & $\mathrm{~A}^{\prime \prime}$ & Twist $\left(\mathrm{CH}_{3}\right)^{1}(47.9)+\gamma$ ring $3(27.6)+$ Twist $\left(\mathrm{CH}_{3}\right)^{2}(16.6)$ \\
\hline & & 115.7 & 0.2 & $\mathrm{~A}^{\prime \prime}$ & Twist $\left(\mathrm{CH}_{3}\right)^{2}(63.1)+\gamma$ ring $3(23.4)$ \\
\hline
\end{tabular}

a PED's lower than $10 \%$ are not included. Definition of symmetry coordinates is given in Table 1 . See Fig. 1 for atom numbering.

${ }^{b}$ Relative integrated intensities.

${ }^{\mathrm{c}}$ Theoretical positions of absorption bands above $2900 \mathrm{~cm}^{-1}$ were scaled down by a factor of 0.968 and below $2000 \mathrm{~cm}^{-1}$ by a factor 0.978 .

substituted with methyl groups, this effect should promote photoreactions originating from the $\pi \pi^{*}$ state, whereas the reactions typical for the $n \pi^{*}$ states (prevailing for unsubstituted species) should be hindered. Strong domination of the Dewar form creation over the $\alpha$-bond cleavage, observed in the current work for 4,6-dimethyl- $\alpha$-pyrone, illustrates well the influence of methyl substitution on relative effectiveness of the $\pi \pi^{*}$ and $n \pi^{*}$ photochemical channels.

When the UV $(\lambda>315 \mathrm{~nm})$ irradiated matrix was subsequently subjected to shorter wavelength UV radiation $(\lambda>$
$235 \mathrm{~nm}$ ), evolution of $\mathrm{CO}_{2}$ was observed and 1,3-dimethylcyclobutadiene (DMCB) was created. The $\mathrm{CO}_{2}$ produced from DOOBH fragmentation could be easily identified spectroscopically by observation of the very intense characteristic IR absorption region around $2337.5 \mathrm{~cm}^{-1}$.

After photolysis, the photoproduced $\mathrm{CO}_{2}$ and DMCB must be confined in the same matrix cavity and they form a complex. The DFT(B3LYP)/6-311++G(d,p) calculations predict that the $\mathrm{CO}_{2}-\mathrm{DMCB}$ complex has a stacking (parallel) geometry (Fig. 6). Fig. 7 represents two potential scans

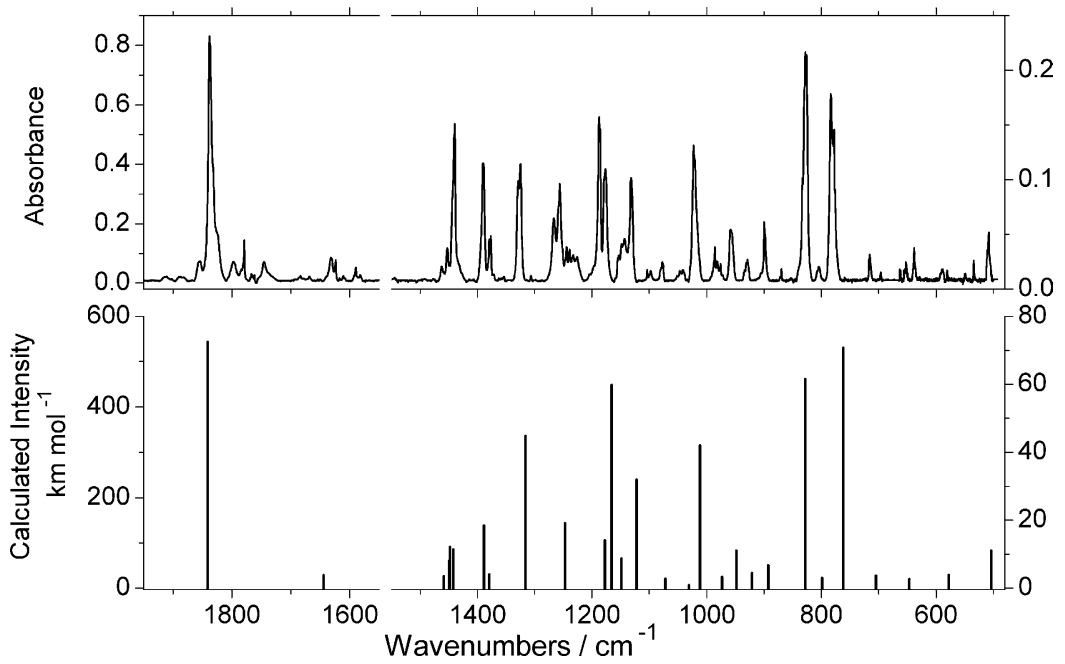

Fig. 5. Comparison of the experimental IR spectrum of the Dewar valence isomer (DOOBH), photogenerated upon UV ( $\lambda>315$ nm) irradiation of DMAP isolated in Ar matrix $(10 \mathrm{~K})$, with the spectrum of DOOBH theoretically predicted at the DFT(B3LYP)/6-311++G(d,p) level. Theoretical frequencies were scaled using a factor equal to 0.978 . Note the change of ordinate scale at $1500 \mathrm{~cm}^{-1}$. 
Table 5

Observed and calculated vibrational frequencies, intensities and potential energy distributions (PED) for DOOBH monomer (frequencies $(v)$ in $\mathrm{cm}^{-1}$, theoretical intensities $(I)$ in $\mathrm{km} \mathrm{mol}^{-1}$ )

\begin{tabular}{|c|c|c|c|c|}
\hline \multicolumn{2}{|c|}{$\begin{array}{l}\text { Observed (infrared, Ar } \\
\text { matrix, } T=10 \mathrm{~K} \text { ) }\end{array}$} & \multicolumn{2}{|c|}{$\begin{array}{l}\text { Calculated } \\
(B 3 L Y P / 6-311++G(d, p)) \\
\end{array}$} & \multirow[t]{2}{*}{$\operatorname{PED}^{\mathrm{a}}(\%)$} \\
\hline$v$ & $I^{\mathrm{b}}$ & $v^{\mathrm{c}}$ & $I$ & \\
\hline 3062.5 & 1.5 & 3091.8 & 8.3 & $v(\mathrm{C} 5-\mathrm{H} 12)(99.1)$ \\
\hline 3005.7 & & 3016.5 & 11.2 & $v(\mathrm{C} 3-\mathrm{H} 17)(99.4)$ \\
\hline 2997.7 & 35.7 & 3011.1 & 13.0 & $v\left(\mathrm{CH}_{3}\right)_{\text {as }}^{1^{\prime \prime}}(97.4)$ \\
\hline 2990.1 & & 3005.9 & 14.1 & $v\left(\mathrm{CH}_{3}\right)_{\mathrm{as}}^{2^{\prime}}(97.7)$ \\
\hline 2984.4 & & 2998.6 & 12.0 & $v\left(\mathrm{CH}_{3}\right)_{\text {as }}^{1^{\prime}}(97.1)$ \\
\hline 2958.8 & 8.3 & 2971.3 & 8.7 & $v\left(\mathrm{CH}_{3}\right)_{\text {as }}^{2 \prime \prime}(100.2)$ \\
\hline 2940.8 & 8.2 & 2936.4 & 13.9 & $v\left(\mathrm{CH}_{3}\right)_{\mathrm{s}}^{1}(99.3)$ \\
\hline \multicolumn{5}{|l|}{2937.5} \\
\hline 2923.8 & 4.7 & 2924.2 & 14.6 & $v\left(\mathrm{CH}_{3}\right)_{\mathrm{s}}^{2}(97.6)$ \\
\hline 1854.1 & 22.3 & & & \\
\hline 1837.7 & 444.8 & 1841.6 & 543.7 & $v(\mathrm{C} 2=\mathrm{O} 7)(88.1)$ \\
\hline 1631.5 & 41.0 & 1644.7 & 28.9 & $v(\mathrm{C} 5=\mathrm{C} 4)(76.1)+v(\mathrm{C} 4-\mathrm{C} 13)$ \\
\hline \multicolumn{5}{|r|}{ (2) } \\
\hline 1462.2 & 2.8 & 1458.7 & 3.5 & $\delta\left(\mathrm{CH}_{3}\right)_{\mathrm{as}}^{1^{\prime \prime}}(84.2)$ \\
\hline 1452.8 & 4.8 & 1449.5 & 8.0 & $\delta\left(\mathrm{CH}_{3}\right)_{\text {as }}^{1^{\prime}}(80.5)$ \\
\hline \multirow[t]{2}{*}{1439.9} & 42.5 & 1447.9 & 12.2 & $\delta\left(\mathrm{CH}_{3}\right)_{\mathrm{as}}^{2^{\prime}}(84.3)$ \\
\hline & & 1441.9 & 11.4 & $\delta\left(\mathrm{CH}_{3}\right)_{\mathrm{as}}^{2^{\prime \prime \prime}}(89.8)$ \\
\hline 1389.6 & 29.7 & 1388.4 & 18.5 & $\delta\left(\mathrm{CH}_{3}\right)_{\mathrm{s}}^{1}(83.9)+v(\mathrm{C} 6-\mathrm{C} 8)(10.7)$ \\
\hline \multicolumn{5}{|r|}{ (1) } \\
\hline 1376.7 & 9.7 & 1379.6 & 4.1 & $\delta\left(\mathrm{CH}_{3}\right)_{\mathrm{s}}^{2}(93.9)$ \\
\hline 1328.0 & 41.8 & & & \\
\hline 1324.5 & & 1316.0 & 44.8 & $\begin{array}{l}v(\mathrm{C} 6-\mathrm{C} 8)(22.6)+v(\mathrm{C} 5-\mathrm{C} 6)(18.3)+v(\mathrm{C} 3-\mathrm{C} 6)(14.6)+\delta\left(\mathrm{CH}_{3}\right)_{\mathrm{s}}^{1}(12.3) \\
+\delta(\mathrm{C} 5-\mathrm{H} 12)(11.1)\end{array}$ \\
\hline \multicolumn{5}{|r|}{ 年 } \\
\hline 1255.9 & 50.9 & 1247.0 & 19.1 & $v(\mathrm{C} 3-\mathrm{C} 4)(21.1)+\gamma\left(\mathrm{CH}_{3}\right)_{\text {as }}^{2^{\prime}}(11.3)$ \\
\hline 1187.7 & 42.4 & 1177.4 & 14.1 & $\gamma(\mathrm{C} 3-\mathrm{H} 17)(55.7)$ \\
\hline 1177.3 & 37.1 & 1165.5 & 59.7 & $v(\mathrm{C} 2-\mathrm{O} 1)(20.8)+\delta(\mathrm{C} 5-\mathrm{H} 12)(11.5)+\delta(\mathrm{C} 3-\mathrm{H} 17)(10.7)+\gamma\left(\mathrm{CH}_{3}\right)_{\text {as }}^{l^{\prime \prime}}(9.7)$ \\
\hline 1154.4 & 28.3 & & & \\
\hline 1143.9 & & 1148.5 & 8.8 & $\gamma\left(\mathrm{CH}_{3}\right)_{\text {as }}^{1^{\prime}}(16.3)+\gamma\left(\mathrm{CH}_{3}\right)_{\text {as }}^{1^{\prime \prime}}(15.9)+\delta(\mathrm{C} 5-\mathrm{H} 12)(19.1)$ \\
\hline 1132.0 & 34.4 & 1122.1 & 32.0 & $\delta(\mathrm{C} 5-\mathrm{H} 12)(17.4)+v(\mathrm{C} 4-\mathrm{C} 13)(17.1)+\gamma(\mathrm{C} 3-\mathrm{H} 17)(15.8)+\delta(\mathrm{C} 3-\mathrm{H} 17)$ \\
\hline 1077.3 & 3.3 & 1072.0 & 2.8 & $\delta(\mathrm{C} 3-\mathrm{H} 17)(30.0)+v(\mathrm{C} 6-\mathrm{C} 8)(13.5)$ \\
\hline 1046.0 & 5.1 & 1031.1 & 0.9 & $\gamma\left(\mathrm{CH}_{3}\right)_{\mathrm{as}}^{2^{\prime \prime}}(69.5)+\gamma(\mathrm{C} 4-\mathrm{C} 13)(10.8)$ \\
\hline \multicolumn{5}{|r|}{$\mathrm{C}$} \\
\hline 1022.3 & 48.2 & 1011.8 & 42.0 & $\gamma\left(\mathrm{CH}_{3}\right)_{\text {as }}^{l^{\prime \prime}}(29.7)+v(\mathrm{C} 2-\mathrm{O} 1)(21.0)+\gamma\left(\mathrm{CH}_{3}\right)_{\text {as }}^{l^{\prime}}(15.1)$ \\
\hline 986.0 & & 973.6 & 3.4 & $\gamma\left(\mathrm{CH}_{3}\right)_{\text {as }}^{2^{\prime}}(21.3)+\delta(\mathrm{C} 3-\mathrm{H} 17)(19.8)+\delta$ ring $2(11.3)+v(\mathrm{C} 4-\mathrm{C} 13)$ \\
\hline 981.9 & 12.0 & & & \\
\hline \multicolumn{5}{|r|}{ 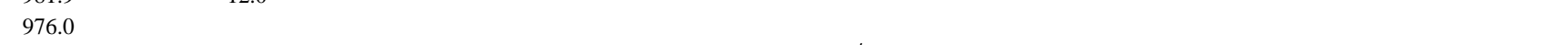 } \\
\hline 957.8 & 17.3 & 948.0 & 11.1 & $\gamma\left(\mathrm{CH}_{3}\right)_{\text {as }}^{2^{\prime}}(25.9)+v(\mathrm{C} 2-\mathrm{C} 3)(12.7)+\delta$ ring $1(11.1)$ \\
\hline 928.9 & 5.4 & 920.8 & 4.6 & $v(\mathrm{C} 4-\mathrm{C} 3)(17.0)+v(\mathrm{C} 5-\mathrm{C} 6)(16.7)+v(\mathrm{C} 2-\mathrm{C} 3)(13.6)+\delta \operatorname{ring} 2(12.1)$ \\
\hline 900.0 & 9.8 & 892.9 & 6.7 & $\gamma\left(\mathrm{CH}_{3}\right)_{\text {as }}^{1^{\prime}}(20.5)+v(\mathrm{C} 5-\mathrm{C} 6)(11.6)+v(\mathrm{C} 3-\mathrm{C} 6)(10.3)$ \\
\hline 827.4 & 71.3 & 828.0 & 61.6 & $\gamma(\mathrm{C} 5-\mathrm{H} 12)(76.2)$ \\
\hline 804.8 & 3.2 & 799.0 & 3.1 & $\gamma(\mathrm{C} 2=\mathrm{O} 7)(23.4)+v(\mathrm{C} 3-\mathrm{C} 6)(17.5)$ \\
\hline 783.6 & 74.9 & 761.9 & 70.7 & $v(\mathrm{O} 1-\mathrm{C} 6)(53.8)+v(\mathrm{C} 2-\mathrm{O} 1)(22.8)$ \\
\hline \multicolumn{5}{|r|}{ (1) } \\
\hline 715.1 & 2.9 & 705.2 & 3.8 & $\gamma(\mathrm{C} 2=\mathrm{O} 7)(15.4)+\delta(\mathrm{C} 2=\mathrm{O} 7)(13.0)+\tau \operatorname{ring} 2(11.1)$ \\
\hline 638.1 & 4.1 & 646.4 & 2.7 & $\delta$ ring $1(21.4)+v(\mathrm{C} 4-\mathrm{C} 13)(14.3)+v(\mathrm{C} 3-\mathrm{C} 4)(11.8)$ \\
\hline 588.9 & 4.5 & 577.9 & 4.0 & $v(\mathrm{C} 6-\mathrm{C} 8)(25.2)+\delta$ ring $2(20.0)+v(\mathrm{C} 4-\mathrm{C} 13)(13.4)$ \\
\hline 509.3 & 10.3 & 503.6 & 11.0 & $\gamma(\mathrm{C} 2=\mathrm{O} 7)(20.4)+\tau \operatorname{ring} 2(18.8)+\delta(\mathrm{C} 2=\mathrm{O} 7)(18.6)$ \\
\hline 443.3 & 8.0 & 438.7 & 6.7 & $\gamma(\mathrm{C} 4-\mathrm{C} 13)(34.1)+\tau$ butterfly $(32.1)$ \\
\hline \multirow[t]{8}{*}{428.2} & 2.9 & 421.4 & 2.1 & $\delta(\mathrm{C} 2=\mathrm{O} 7)(23.7)+\tau$ butterfly $(12.7)+v(\mathrm{O} 1-\mathrm{C} 6)(9.8)+\tau$ ring $2(9.8)$ \\
\hline & & 346.5 & 3.6 & $\delta(\mathrm{C} 4-\mathrm{C} 13)(30.8)+\delta(\mathrm{C} 6-\mathrm{C} 8)(18.1)+\tau$ butterfly $(11.4)$ \\
\hline & & 316.8 & 1.9 & $\gamma(\mathrm{C} 6-\mathrm{C} 8)(42.2)$ \\
\hline & & 228.0 & 0.2 & $\delta(\mathrm{C} 6-\mathrm{C} 8)(46.8)+\delta(\mathrm{C} 4-\mathrm{C} 13)(31.3)$ \\
\hline & & 213.6 & 0.05 & Twist $\left(\mathrm{CH}_{3}\right)^{1}(92.9)$ \\
\hline & & 162.6 & 0.06 & Twist $\left(\mathrm{CH}_{3}\right)^{2}(84.7)$ \\
\hline & & 133.1 & 1.1 & $\tau$ ring $1(29.0)+\gamma(\mathrm{C} 6-\mathrm{C} 8)(21.7)+\tau$ ring $2(18.0)+$ Twist $\left(\mathrm{CH}_{3}\right)^{2}(13.2)$ \\
\hline & & 125.7 & 3.3 & $\begin{array}{l}\gamma(\mathrm{C} 4-\mathrm{C} 13)(25.3)+\tau \text { butterfly }(20.7)+\tau \text { ring } 1(14.9)+\gamma(\mathrm{C} 2=\mathrm{O} 7)(13.6)+\tau \\
\text { ring } 2(11.2)\end{array}$ \\
\hline
\end{tabular}

\footnotetext{
a PED's lower than $10 \%$ are not included. Definition of symmetry coordinates is given in Table 2. See Fig. 3 for atom numbering.

${ }^{\mathrm{b}}$ Relative integrated intensities.

${ }^{\mathrm{c}}$ Theoretical positions of absorption bands above $2900 \mathrm{~cm}^{-1}$ were scaled down by a factor of 0.968 and below $2000 \mathrm{~cm}^{-1}$ by a factor 0.978 .
} 
(A)

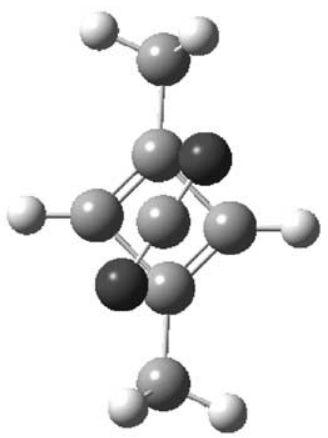

$(\mathrm{C})$

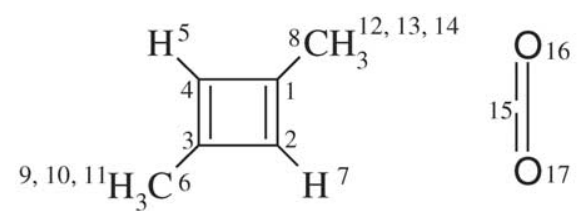

Fig. 6. Dimethylcyclobutadiene complex with $\mathrm{CO}_{2}$. (A) Stacking (parallel) dimer, corresponding to the unique theoretically predicted minimum on the PES of this system. (B) Axial configuration of the dimer (not a minimum; see text). (C) Atom numbering used in the normal mode analysis of the complex.

for the $\mathrm{CO}_{2}-\mathrm{DMCB}$ complex assuming two different orientations within the $\mathrm{C}_{2}$ symmetry framework: one with the axial orientation and the other with the parallel orientation to the DMCB plane (see also Fig. 6). The first scan (axial) reveals a repulsive potential of interaction between $\mathrm{CO}_{2}$ and DMCB. On the other hand, the second one (parallel) shows a binding profile with an equilibrium minimum energy distance between the two molecules of ca. $3.44 \AA$ and a stabilization energy of the complex equal to $4.7 \mathrm{~kJ} \mathrm{~mol}^{-1}$.
The main geometric parameters for both DOOBH and $\mathrm{CO}_{2}-\mathrm{DMCB}$ complex are listed in Tables 6 and 7. Calculations performed at the DFT(B3LYP)/6-311++G(d,p) level of theory do not predict any other minima for the $\mathrm{CO}_{2}-\mathrm{DMCB}$ system.

Fig. 8 clearly demonstrates the formation of the $\mathrm{CO}_{2}-$ DMCB complex from DOOBH. DOOBH was produced first by irradiation of the matrix with UV light $(\lambda>315 \mathrm{~nm})$ and dominated in the sample at this stage of the experiment

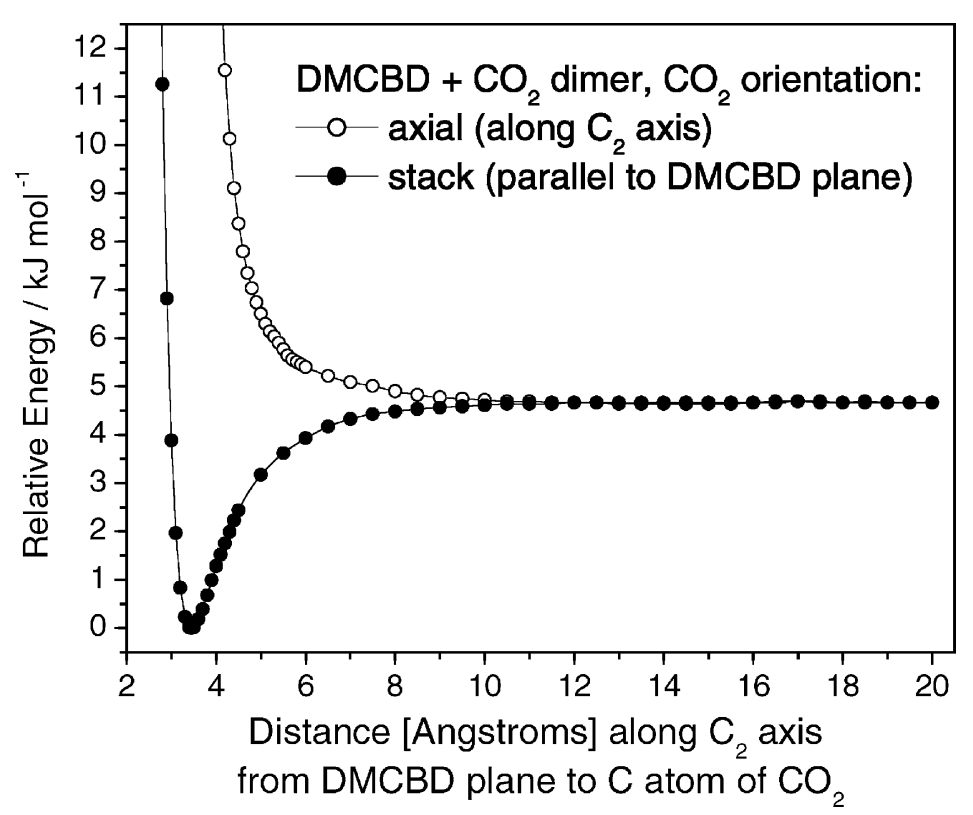

Fig. 7. Energy of the dimethylcyclobutadiene complex with $\mathrm{CO}_{2}$ as a function of the distance between the two molecules. Energies were calculated at the DFT(B3LYP)/6-311++G(d,p) level for the structures obtained by fixing the distance between DMCBD and $\mathrm{CO}_{2}$ and optimizing all other geometry parameters. Two relative orientations of the two molecules (parallel and axial—see Fig. 6) have been considered. $\mathrm{C}_{2}$ symmetry axis was conserved in all the calculations. Zero-level of energy corresponds to -422.039897 hartrees. 

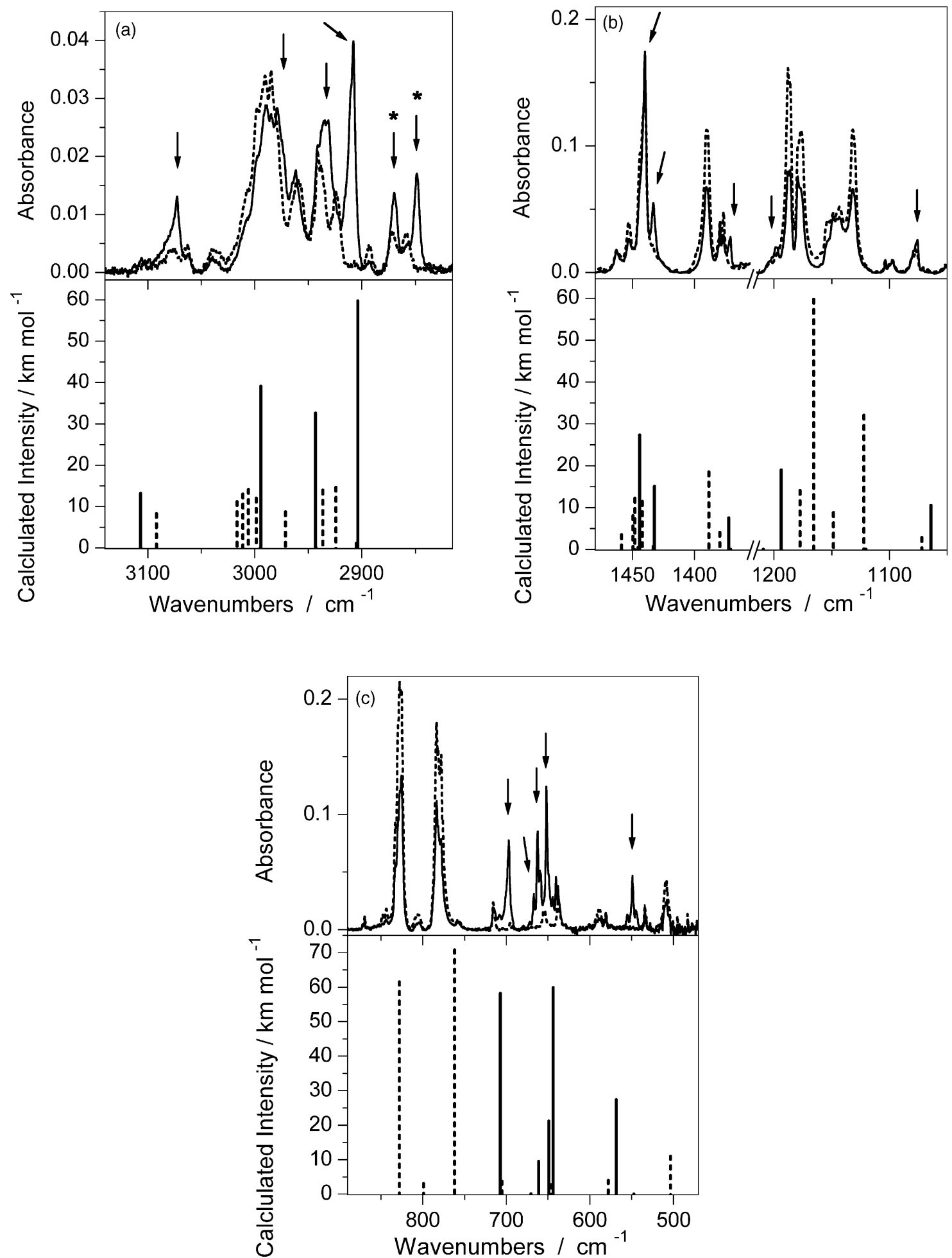

Fig. 8. Experimental evidence of photogeneration of the DMCB- $\mathrm{CO}_{2}$ complex upon UV $(\lambda>235 \mathrm{~nm})$ irradiation of DOOBH isolated in Ar matrix $(10 \mathrm{~K})$. The experimental spectrum presented (in upper panel) with dashed line is dominated by the bands due to Dewar valence isomer (DOOBH), produced by preceding UV $(\lambda>315 \mathrm{~nm})$ irradiation. The spectrum presented with solid line was recorded after 360 min of subsequent UV $(\lambda>235 \mathrm{~nm})$ irradiation. The growing bands correspond to the DMCB- $-\mathrm{CO}_{2}$ dimer and are indicated with arrows. Asterisks indicate bands assigned to overtones or combination tones. The spectra theoretically predicted at the DFT(B3LYP)/6-311++G(d,p) level are presented (in lower panel) in the stick spectrum form. In all the regions dashed sticks correspond to the spectrum of DOOBH and solid sticks to the spectrum of the $\mathrm{DMCB}^{-\mathrm{CO}_{2}}$ stacking complex. Theoretical frequencies were scaled using a factor equal to 0.978 (except for the $\mathrm{CH}$ stretching region, where the factor 0.968 was used). 
Table 6

Bond distances, bond angles in four-membered rings, and total electronic energy $(\mathrm{E}(\mathrm{RB}+\mathrm{HF}-\mathrm{LYP})=-422.0621471$, in hartrees) at the geometry optimized at the B3LYP/6-311++G(d,p) level for DOOBH (atom numbering as in Fig. 3)

\begin{tabular}{llll}
\hline Bond distances $(\AA)$ & & & \\
O1-C2 & 1.3695 & C8-H9 & 1.0928 \\
C2-C3 & 1.5313 & C8-H10 & 1.0937 \\
C3-C4 & 1.5352 & C8-H11 & 1.0920 \\
C4=C5 & 1.3435 & C5-H12 & 1.0833 \\
C5-C6 & 1.5151 & C4-C13 & 1.4858 \\
C6-O1 & 1.5078 & C13-H14 & 1.0919 \\
C6-C3 & 1.5523 & C13-H15 & 1.0951 \\
C2=O7 & 1.1926 & C13-H16 & 1.0951 \\
C6-C8 & 1.5001 & C3-H17 & 1.0892 \\
Bond angles ${ }^{\mathrm{a}}\left(^{\circ}\right)$ & & & \\
C6-O1-C2 & 91.77 & C6-C5-C4 & 93.90 \\
C6-C3-C2 & 84.23 & C6-C3-C4 & 85.32 \\
O1-C6-C3 & 88.89 & C5-C4-C3 & 93.94 \\
O1-C2-C3 & 95.09 & C5-C6-C3 & 86.83 \\
\hline
\end{tabular}

${ }^{\mathrm{a}} \mathrm{A}-\mathrm{B}-\mathrm{C}$ is the angle between bonds $\mathrm{A}-\mathrm{C}$ and $\mathrm{B}-\mathrm{C}$.

(dashed line in Fig. 8). Further irradiation with shorter wavelengths led to decrease of the bands originated in DOOBH and appearance of new bands due to the $\mathrm{CO}_{2}-\mathrm{DMCB}$ complex (the solid line in Fig. 8 corresponds to the spectrum obtained after $360 \mathrm{~min}$ of irradiation with $\lambda>235 \mathrm{~nm}$ ). A close inspection of the observed profile of the characteristic $\mathrm{CO}_{2}$ feature at $2341.7-2337.7 \mathrm{~cm}^{-1}$, due to the $\mathrm{CO}_{2}$ asymmetric stretching vibration is presented in Fig. 9, and clearly reveals that $\mathrm{CO}_{2}$ must be associated. Indeed, this feature is observed as a broad complex band, which is red-shifted relatively to the doublet observed for the free $\mathrm{CO}_{2}$ monomer isolated in argon. The later has components at 2345.0 and $2339.1 \mathrm{~cm}^{-1}$, with full width at half maximum equal to only $0.2 \mathrm{~cm}^{-1}$ [17]. As shown in Fig. 8, the IR spectrum calculated for the stacked $\mathrm{CO}_{2}-\mathrm{DMCB}$ complex fits nicely the experimental spectrum of the photoproduct(s) generated

Table 7

Bond distances, bond angles in four-membered ring, and total electronic energy $(\mathrm{E}(\mathrm{RB}+\mathrm{HF}-\mathrm{LYP})=-422.03989725$ Energy of the DMCB$\mathrm{CO}_{2}$ complex in hartrees) at the geometry optimized at the B3LYP/6$311++\mathrm{G}(\mathrm{d}, \mathrm{p})$ level for 1,3-dimethyl-cyclobutadiene in the $\mathrm{DMCB}-\mathrm{CO}_{2}$ complex (atom numbering as in Fig. 6)

\begin{tabular}{|c|c|c|c|}
\hline \multicolumn{4}{|c|}{ Bond distances $(\AA)$} \\
\hline $\mathrm{C} 1=\mathrm{C} 2$ & 1.3382 & $\mathrm{C} 1-\mathrm{C} 8$ & 1.4794 \\
\hline $\mathrm{C} 2-\mathrm{C} 3$ & 1.5776 & C6-H9 & 1.0926 \\
\hline $\mathrm{C} 3=\mathrm{C} 4$ & 1.3382 & C6-H10 & 1.0967 \\
\hline $\mathrm{C} 4-\mathrm{C} 1$ & 1.5776 & C6-H11 & 1.0972 \\
\hline $\mathrm{C} 4-\mathrm{H} 5$ & 1.0818 & $\mathrm{C} 8-\mathrm{H} 12$ & 1.0926 \\
\hline C3-C6 & 1.4794 & C8-H13 & 1.0967 \\
\hline $\mathrm{C} 2-\mathrm{H} 7$ & 1.0818 & C8-H14 & 1.0972 \\
\hline \multicolumn{4}{|c|}{ Bond angles $^{\mathrm{a}}\left({ }^{\circ}\right)$} \\
\hline $\mathrm{C} 1-\mathrm{C} 2-\mathrm{C} 3$ & 89.67 & $\mathrm{C} 3-\mathrm{C} 4-\mathrm{C} 1$ & 89.67 \\
\hline $\mathrm{C} 2-\mathrm{C} 3-\mathrm{C} 4$ & 90.33 & $\mathrm{C} 4-\mathrm{C} 1-\mathrm{C} 2$ & 90.33 \\
\hline
\end{tabular}

\footnotetext{
${ }^{\mathrm{a}} \mathrm{A}-\mathrm{B}-\mathrm{C}$ is the angle between bonds $\mathrm{A}-\mathrm{C}$ and $\mathrm{B}-\mathrm{C}$.
}

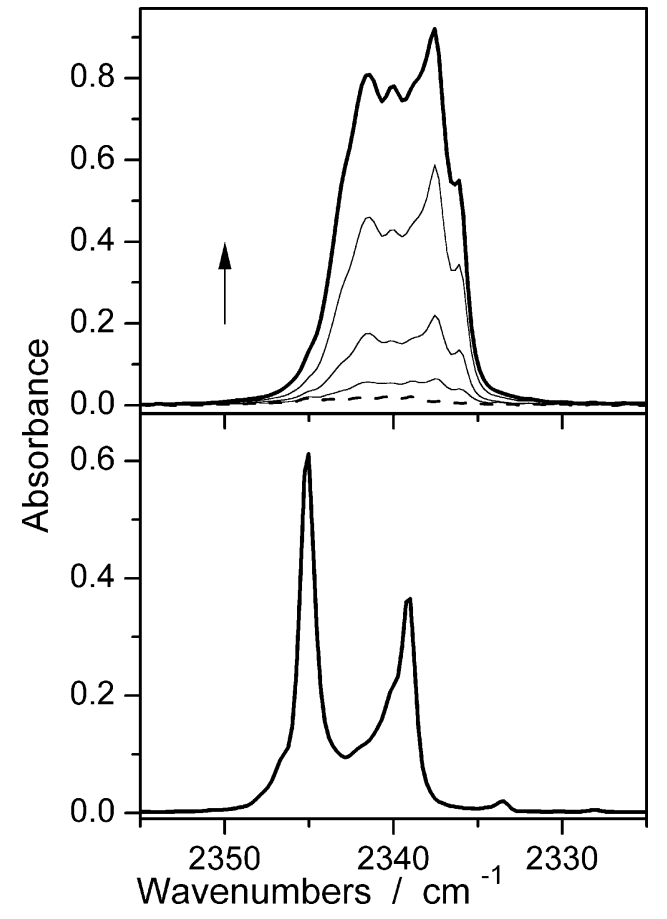

Fig. 9. Upper panel: Increase of the IR band due to $\mathrm{CO}_{2}$ antisymmetric vibration during the progress $(t=0,15,60,180$ and $360 \mathrm{~min})$ of $\mathrm{UV}$ $(\lambda>235 \mathrm{~nm})$ irradiation of DOOBH isolated in Ar matrix $(10 \mathrm{~K})$; lower panel: the same region of IR spectrum of a matrix obtained (in a separate experiment) by co-deposition of $\mathrm{CO}_{2}$ and argon.

upon irradiation of the matrix with UV $(\lambda>235 \mathrm{~nm})$ light. Table 8 summarizes the proposed band assignments for this species. The most intense IR bands due to the bending vibrations of the methyl groups were found in the experimental spectrum at $1439.9,1433.2$ and $1371.2 \mathrm{~cm}^{-1}$ and the $\mathrm{C}-\mathrm{H}$ asymmetric in-plane bending mode at $1198.3 \mathrm{~cm}^{-1}$, in good agreement with the theoretical predictions (1444.1, $1432.1,1372.4$ and $1193.6 \mathrm{~cm}^{-1}$, respectively), while the bands predicted at 1064.0, 1016.4 and $661.3 \mathrm{~cm}^{-1}$ have their experimental counterparts at 1075.6, 1012.3 and $667.0 \mathrm{~cm}^{-1}$. The $\mathrm{C}-\mathrm{H}$ out-of-plane bending vibration of the cyclobutadiene ring hydrogen atoms was predicted to give rise to a strong band at $707.1 \mathrm{~cm}^{-1}$ and was observed in the experimental spectrum at $696.9 \mathrm{~cm}^{-1}$. On the other hand, the two $\mathrm{CO}_{2}$ bending vibrations, which in the $\mathrm{CO}_{2}$ monomer are degenerated by symmetry, were predicted by the calculations to appear in the $\mathrm{CO}_{2}-\mathrm{DMCB}$ at 649.2 and $644.1 \mathrm{~cm}^{-1}$ and, accordingly, were observed at $662.6 / 659.8$ and $652.1 \mathrm{~cm}^{-1}$. The band due to the four-membered ring puckering ( $\tau$ ring; calculated frequency: $568.3 \mathrm{~cm}^{-1}$ ) was observed at $549.3 / 544.3 \mathrm{~cm}^{-1}$. This band is a direct analogue of the ring puckering band observed for unsubstituted cyclobutadiene at $573 \mathrm{~cm}^{-1}$ [18]. In the high frequency spectral region, the three intense methyl stretching bands were observed at $2973.7,2931.2$ and $2907.6 \mathrm{~cm}^{-1}$, while the $\mathrm{C}_{\text {ring }}-\mathrm{H}$ asymmetric stretching was found at $3072.4 \mathrm{~cm}^{-1}$, also in good agreement with the theoretical predictions (see 
Table 8

Observed and calculated vibrational frequencies, intensities and potential energy distributions (PED) for DMCB stacked to $\mathrm{CO}_{2}$ monomer (frequencies (v) in $\mathrm{cm}^{-1}$, theoretical intensities $(I)$ in $\mathrm{km} \mathrm{mol}^{-1}$ )

\begin{tabular}{|c|c|c|c|c|c|}
\hline \multicolumn{2}{|c|}{$\begin{array}{l}\text { Observed (infrared, Ar } \\
\text { matrix, } T=10 \mathrm{~K} \text { ) }\end{array}$} & \multicolumn{2}{|c|}{$\begin{array}{l}\text { Calculated } \\
(\text { B3LYP/6-311++G(d,p)) }\end{array}$} & \multirow[t]{2}{*}{ Symmetry } & \multirow[t]{2}{*}{$\operatorname{PED}^{\mathrm{a}}(\%)$} \\
\hline$v$ & $I^{\mathrm{b}}$ & $v^{\mathrm{c}}$ & $I$ & & \\
\hline \multirow[t]{3}{*}{3072.4} & 13.2 & 3106.6 & 13.1 & B & $v(\mathrm{C}-\mathrm{H})_{\text {as }}(99.1)$ \\
\hline & & 3106.4 & 0.03 & A & $v(\mathrm{C}-\mathrm{H})_{\mathrm{s}}(99.1)$ \\
\hline & & 2994.7 & 0.007 & A & $v\left(\mathrm{CH}_{3}\right)_{\mathrm{as}}(94.6)$ \\
\hline \multicolumn{6}{|l|}{2988.1} \\
\hline 2973.6 & 39.2 & 2994.3 & 39.1 & $\mathrm{~B}$ & $v\left(\mathrm{CH}_{3}\right)_{\mathrm{as}}^{\prime}(94.5)$ \\
\hline \multicolumn{6}{|l|}{2962.0} \\
\hline \multirow[t]{3}{*}{2931.2} & 31.0 & 2943.2 & 32.6 & A & $v\left(\mathrm{CH}_{3}\right)_{\mathrm{as}}^{\prime \prime}(99.6)$ \\
\hline & & 2943.0 & 0.1 & B & $v\left(\mathrm{CH}_{3}\right)_{\mathrm{as}}^{\prime \prime \prime}(99.6)$ \\
\hline & & 2905.2 & 1.1 & $\mathrm{~A}$ & $v\left(\mathrm{CH}_{3}\right)_{\mathrm{s}}(94.8)$ \\
\hline 2907.6 & 32.3 & 2903.8 & 59.7 & $\mathrm{~B}$ & $v\left(\mathrm{CH}_{3}\right)_{\mathrm{s}}^{\prime}(94.7)$ \\
\hline 2869.4 & 9.1 & & & & Overtone $\left(\delta\left(\mathrm{CH}_{3}\right)_{\text {as }}^{\prime \prime \prime}\right)$ \\
\hline 2848.6 & 11.7 & & & & Overtone $\left(\delta\left(\mathrm{CH}_{3}\right)_{\text {as }}\right)$ \\
\hline \multirow[t]{4}{*}{2337.5} & 571.0 & 2340.7 & 511.1 & $\mathrm{~B}$ & $v\left(\mathrm{CO}_{2}\right)_{\text {as }}(100.0)$ \\
\hline & & 1663.6 & 32.5 & $\mathrm{~B}$ & $v(\mathrm{C}=\mathrm{C})_{\mathrm{as}}(74.4)+v\left(\mathrm{C}-\mathrm{CH}_{3}\right)_{\mathrm{as}}$ \\
\hline & & 1650.5 & 0.2 & A & $v(\mathrm{C}=\mathrm{C})_{\mathrm{s}}(77.7)+v\left(\mathrm{C}-\mathrm{CH}_{3}\right)_{\mathrm{s}}(15.4)$ \\
\hline & & 1445.5 & 0.4 & A & $\delta\left(\mathrm{CH}_{3}\right)_{\mathrm{as}}^{\prime \prime}(58.7)+\delta\left(\mathrm{CH}_{3}\right)_{\mathrm{as}}(31.2)$ \\
\hline \multirow[t]{2}{*}{1439.9} & 36.9 & 1444.1 & 27.3 & $\mathrm{~B}$ & $\delta\left(\mathrm{CH}_{3}\right)_{\mathrm{as}}^{\prime \prime \prime}(57.2)+\delta\left(\mathrm{CH}_{3}\right)_{\mathrm{as}}^{\prime}(32.9)$ \\
\hline & & 1433.3 & 0.7 & $\mathrm{~B}$ & $\delta\left(\mathrm{CH}_{3}\right)_{\mathrm{as}}^{\prime}(58.2)+\delta\left(\mathrm{CH}_{3}\right)_{\mathrm{as}}^{\prime \prime \prime}(33.0)$ \\
\hline 1433.2 & 19.9 & 1432.1 & 15.0 & A & $\delta\left(\mathrm{CH}_{3}\right)_{\mathrm{as}}(60.2)+\delta\left(\mathrm{CH}_{3}\right)_{\mathrm{as}}^{\prime \prime}(31.4)$ \\
\hline \multirow[t]{4}{*}{1371.2} & 8.3 & 1372.4 & 7.5 & $\mathrm{~B}$ & $\delta\left(\mathrm{CH}_{3}\right)_{\mathrm{s}}^{\prime}(95.4)$ \\
\hline & & 1371.0 & 0.03 & A & $\delta\left(\mathrm{CH}_{3}\right)_{\mathrm{s}}(95.1)$ \\
\hline & & 1342.6 & 0.1 & A & $v\left(\mathrm{CO}_{2}\right)_{\mathrm{s}}(100.0)$ \\
\hline & & 1209.1 & 0.003 & $\mathrm{~A}$ & $v(\mathrm{C}-\mathrm{C})_{\mathrm{s}}(33.0)+v\left(\mathrm{C}-\mathrm{CH}_{3}\right)_{\mathrm{s}}(29.1)+\delta(\mathrm{C}-\mathrm{H})_{\mathrm{s}}(10.4)$ \\
\hline \multirow[t]{2}{*}{1198.3} & 8.7 & 1193.6 & 19.0 & B & $\begin{array}{l}\delta(\mathrm{C}-\mathrm{H})_{\mathrm{as}}(41.0)+\gamma\left(\mathrm{CH}_{3}\right)_{\mathrm{as}}^{\prime}(21.4)+v(\mathrm{C}-\mathrm{C})_{\mathrm{as}}(16.6) \\
+\delta\left(\mathrm{C}-\mathrm{CH}_{3}\right)_{\mathrm{as}}(10.6)\end{array}$ \\
\hline & & 1120.4 & 0.004 & A & $\delta(\mathrm{C}-\mathrm{H})_{\mathrm{s}}(65.9)+\gamma\left(\mathrm{CH}_{3}\right)_{\mathrm{as}}(19.6)$ \\
\hline \multirow[t]{2}{*}{1075.6} & 8.5 & 1064.0 & 10.5 & $\mathrm{~B}$ & $\delta(\mathrm{C}-\mathrm{H})_{\text {as }}(43.9)+v\left(\mathrm{C}-\mathrm{CH}_{3}\right)_{\text {as }}(30.1)+\gamma\left(\mathrm{CH}_{3}\right)_{\mathrm{as}}^{\prime}(19.0)$ \\
\hline & & 1025.1 & 0.09 & $\mathrm{~B}$ & $\gamma\left(\mathrm{CH}_{3}\right)_{\text {as }}^{\prime \prime \prime}(80.9)+\gamma\left(\mathrm{C}-\mathrm{CH}_{3}\right)_{\text {as }}$ \\
\hline \multirow[t]{4}{*}{1012.3} & 2.6 & 1016.4 & 3.7 & A & $\gamma\left(\mathrm{CH}_{3}\right)_{\mathrm{as}}^{\prime \prime}(78.9)+\gamma\left(\mathrm{C}-\mathrm{CH}_{3}\right)_{\mathrm{s}}(10.2)$ \\
\hline & & 997.3 & 0.007 & A & $\gamma\left(\mathrm{CH}_{3}\right)_{\mathrm{as}}(34.8)+\delta$ ring $(28.6)+v\left(\mathrm{C}-\mathrm{CH}_{3}\right)_{\mathrm{s}}(11.6)$ \\
\hline & & 921.9 & 4.3 & B & $\gamma\left(\mathrm{CH}_{3}\right)_{\mathrm{as}}^{\prime}(40.3)+v\left(\mathrm{C}-\mathrm{CH}_{3}\right)_{\mathrm{as}}(35.1)+v(\mathrm{C}=\mathrm{C})_{\mathrm{as}}$ \\
\hline & & 892.7 & 0.01 & A & $v(\mathrm{C}-\mathrm{C})_{\mathrm{s}}(45.7)+\delta \operatorname{ring}(17.9)+\gamma\left(\mathrm{CH}_{3}\right)_{\mathrm{as}}(20.8)+\delta(\mathrm{C}-\mathrm{H})_{\mathrm{s}}(13.7)$ \\
\hline \multirow[t]{2}{*}{696.9} & 37.6 & 707.1 & 58.2 & A & $\gamma(\mathrm{C}-\mathrm{H})_{\mathrm{s}}(86.0)+\gamma\left(\mathrm{C}-\mathrm{CH}_{3}\right)_{\mathrm{s}}(11.1)$ \\
\hline & & 670.3 & 0.1 & $\mathrm{~B}$ & $\gamma(\mathrm{C}-\mathrm{H})_{\text {as }}(76.7)$ \\
\hline 667.0 & 4.6 & 661.3 & 9.5 & $\mathrm{~B}$ & $v(\mathrm{C}-\mathrm{C})_{\mathrm{as}}(55.1)+v\left(\mathrm{C}-\mathrm{CH}_{3}\right)_{\mathrm{as}}(13.4)$ \\
\hline 662.6 & 40.8 & 649.2 & 21.2 & $\mathrm{~B}$ & $\delta\left(\mathrm{CO}_{2}\right)_{\text {as }}(88.5)$ \\
\hline \multicolumn{6}{|l|}{659.8} \\
\hline 652.1 & 41.8 & 644.1 & 59.9 & A & $\delta\left(\mathrm{CO}_{2}\right)_{\mathrm{s}}(96.8)$ \\
\hline 644.5 & 3.5 & & & & \\
\hline 640.7 & 8.5 & & & & \\
\hline 555.1 & 3.8 & & & & \\
\hline 549.3 & 18.2 & 568.3 & 27.3 & A & $\tau$ ring $(76.7)+\gamma(\mathrm{C}-\mathrm{H})_{\mathrm{s}}(11.2)$ \\
\hline \multicolumn{6}{|r|}{ 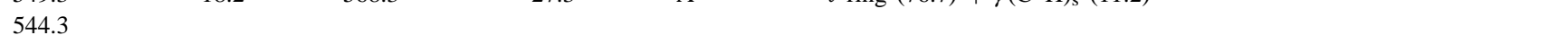 } \\
\hline & & 547.3 & 0.03 & A & $\delta$ ring $(40.6)+v\left(\mathrm{C}-\mathrm{CH}_{3}\right)_{\mathrm{s}}(37.6)+v(\mathrm{C}-\mathrm{C})_{\mathrm{s}}(11.4)$ \\
\hline & & 363.9 & 0.01 & A & $\delta\left(\mathrm{C}-\mathrm{CH}_{3}\right)_{\mathrm{s}}(81.6)$ \\
\hline & & 323.3 & 0.1 & $\mathrm{~B}$ & $\gamma\left(\mathrm{C}-\mathrm{CH}_{3}\right)_{\text {as }}(92.5)$ \\
\hline & & 224.3 & 2.2 & $\mathrm{~B}$ & $\delta\left(\mathrm{C}-\mathrm{CH}_{3}\right)_{\mathrm{as}}(79.4)+v(\mathrm{C}-\mathrm{C})_{\mathrm{as}}(13.1)$ \\
\hline & & 209.7 & 0.01 & $\mathrm{~B}$ & $\tau\left(\mathrm{C}-\mathrm{CH}_{3}\right)^{\prime}(105.4)$ \\
\hline & & 193.6 & 0.003 & A & $\tau\left(\mathrm{C}-\mathrm{CH}_{3}\right)(95.3)$ \\
\hline & & 137.9 & 9.5 & A & $\gamma\left(\mathrm{C}-\mathrm{CH}_{3}\right)_{\mathrm{s}}(66.6)+\tau$ ring $(27.2)$ \\
\hline & & 65.3 & 0.4 & $\mathrm{~B}$ & $\mathrm{CO}_{2}$-ring wag $(104.8)$ \\
\hline & & 42.0 & 0.005 & A & $\mathrm{CO}_{2}$-ring symmetric stretching (98.6) \\
\hline & & 38.7 & 0.003 & $\mathrm{~B}$ & $\mathrm{CO}_{2}$-ring asymmetric stretching $(84.0)+\mathrm{CO}_{2}$-ring wag (18.9) \\
\hline & & 29.4 & 0.005 & A & $\mathrm{CO}_{2}$-ring twist $(99.3)$ \\
\hline & & 20.2 & 0.0008 & $\mathrm{~B}$ & $\mathrm{CO}_{2}$-ring parallel shift $(109.2)+\mathrm{CO}_{2}$-ring asymmetric stretching (15.4) \\
\hline
\end{tabular}

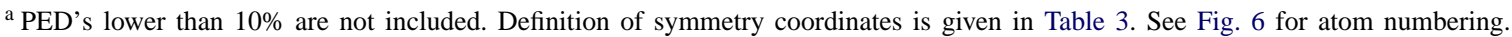

${ }^{\mathrm{b}}$ Relative integrated intensities.

${ }^{\mathrm{c}}$ Theoretical positions of absorption bands above $2900 \mathrm{~cm}^{-1}$ were scaled down by a factor of 0.968 and below $2000 \mathrm{~cm}^{-1}$ by a factor 0.978 .
} 
Table 8 and Fig. 8). Finally, the band due to the antisymmetric stretching vibrations of the two $\mathrm{C}=\mathrm{C}$ bonds is predicted to occur around $1660 \mathrm{~cm}^{-1}$, but its assignment is uncertain since this spectral region does also exhibit relatively intense bands due to traces of matrix isolated water that could not be removed from the set up.

\section{Conclusions}

Several new results on photochemistry of DMAP were obtained by combined usage of matrix isolation technique, FTIR spectroscopy and theoretical simulations of IR spectra. Photochemical valence isomerization of DMAP to its Dewar isomer DOOBH strongly dominated for this molecule when compared with the ring opening, Norrish type I photoprocess leading to the conjugated ketene. In the present study, the photoproduced DOOBH was positively identified by comparison of its experimental and theoretically calculated IR spectrum. In turn, when irradiated using higher energy radiation $(\lambda>235 \mathrm{~nm})$ DOOBH is photolysed to DMCB plus $\mathrm{CO}_{2}$. In the matrix, these two photoproducts form a stacked (parallel) complex, that can be unequivocally identified by comparison of its experimentally observed IR spectrum with the spectrum simulated using the DFT method.

\section{Acknowledgements}

IR, SB and RF acknowledge the financial support from Fundação para a Ciência e a Tecnologia, Lisbon (grant FCT \#SFRH/BPD/1661/2000 and research project POCTI/ 43366/QUI/2001). SB also acknowledges support from the Centre of Excellence ASPECT financed by the European Commission within the contract number G6MA-CT-200204021 .

\section{References}

[1] R.S. Becker, S. Chakravorti, C. Gartner, M.G. Miguel, J. Chem. Soc., Faraday Trans. 89 (1993) 1007.

[2] A. Lopes, J. Seixas de Melo, A.J. Martins, A.L. Maçanita, F.S. Pina, H. Wamhoff, E.C. Mello, Environ. Sci. Technol. 29 (1995) 562.

[3] J. Seixas de Melo, G. Quinteiro, J. Pina, S. Breda, R. Fausto, J. Mol. Struct. 565-566 (2001) 59.

[4] P. de Mayo, Adv. Org. Chem. 2 (1960) 394.

[5] E.J. Corey, J. Streith, J. Am. Chem. Soc. 86 (5) (1964) 950.

[6] J.P. Guthrie, C.L. McIntosh, P. de Mayo, Can. J. Chem. 48 (2) (1970) 237.

[7] A.D. Becke, Phys. Rev. A 38 (6) (1988) 3098

[8] C.T. Lee, W.T. Yang, R.G. Parr, Phys. Rev. B 37 (2) (1988) 785.

[9] S.H. Vosko, L. Wilk, M. Nusair, Can. J. Phys. 58 (8) (1980) 1200.

[10] J.H. Schachtschneider, Emeryville, Shell Development Co., CA, 1969.

[11] M.J. Frisch, G.W. Trucks, H.B. Schlegel, G.E. Scuseria, M.A. Robb, J.R. Cheeseman, V.G. Zakrzewski, J.A. Montgomery Jr., R.E. Stratmann, J.C. Burant, S. Dapprich, J.M. Millam, A.D. Daniels, K.N. Kudin, M.C. Strain, O. Farkas, J. Tomasi, V. Barone, M. Cossi, R. Cammi, B. Mennucci, C. Pomelli, C. Adamo, S. Clifford, J. Ochterski, G.A. Petersson, P.Y. Ayala, Q. Cui, K. Morokuma, D.K. Malick, A.D. Rabuck, K. Raghavachari, J.B. Foresman, J. Cioslowski, J.V. Ortiz, A.G. Baboul, B.B. Stefanov, G. Liu, A. Liashenko, P. Piskorz, I. Komaromi, R. Gomperts, R.L. Martin, D.J. Fox, T. Keith, M.A. Al-Laham, C.Y. Peng, A. Nanayakkara, M. Challacombe, P.M.W. Gill, B. Johnson, W. Chen, M.W. Wong, J.L. Andres, C. Gonzalez, M. Head-Gordon, E.S. Replogle, J.A. Pople, in: Proceedings of the Gaussian'98, Revision A.9, Gaussian, Inc., Pittsburgh, PA, 1998.

[12] L. Lapinski, M.J. Nowak, A. Les, L. Adamowicz, J. Am. Chem. Soc. 116 (4) (1994) 1461.

[13] W.H. Pirkle, L.H. McKendry, J. Am. Chem. Soc. 91 (1969) 1179.

[14] N.J. Turro, in: Modern Molecular Photochemistry, University Science Books, Sausalito, California, 1991, Chapter 13, p. 526.

[15] M. Klessinger, J. Michl, in: Excited States and Photochemistry of Organic Molecules, VCH, New York, 1995, Chapter 7.2.1, p. 380.

[16] R.S. Becker, in: Theory and Interpretation of Fluorescence and Phosphorescence, Wiley/Interscience, New York, 1969.

[17] A. Schriver, L. Schriver-Mazzuoli, A.A. Vigasin, Vib. Spectrosc. 23 (1) (2000) 83-84.

[18] R.G.S. Pong, B.S. Huang, J. Laureni, A. Krantz, J. Am. Chem. Soc. 99 (12) (1977) 4153. 